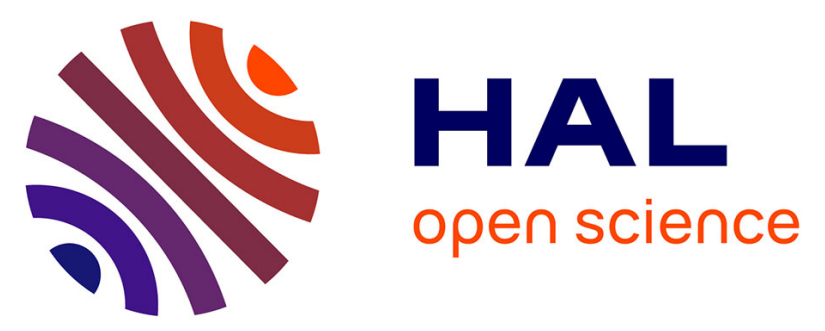

\title{
Elevational variation of body size and reproductive traits in high-latitude wolf spiders (Araneae Lycosidae)
}

Camille Ameline, Tøke Thomas Høye, Joseph James Bowden, Rikke Reisner Hansen, Oskar Liset Pryds Hansen, Charlène Puzin, Philippe Vernon, Julien Pétillon

\section{To cite this version:}

Camille Ameline, Tøke Thomas Høye, Joseph James Bowden, Rikke Reisner Hansen, Oskar Liset Pryds Hansen, et al.. Elevational variation of body size and reproductive traits in high-latitude wolf spiders (Araneae Lycosidae). Polar Biology, 2018, 41 (12), pp.2561-2574. 10.1007/s00300-018-2391-5 . hal-01937629

HAL Id: hal-01937629

https://hal-univ-rennes1.archives-ouvertes.fr/hal-01937629

Submitted on 14 Dec 2018

HAL is a multi-disciplinary open access archive for the deposit and dissemination of scientific research documents, whether they are published or not. The documents may come from teaching and research institutions in France or abroad, or from public or private research centers.
L'archive ouverte pluridisciplinaire HAL, est destinée au dépôt et à la diffusion de documents scientifiques de niveau recherche, publiés ou non, émanant des établissements d'enseignement et de recherche français ou étrangers, des laboratoires publics ou privés. 
1 Elevational variation of body size and reproductive traits in high latitude wolf spiders

2 (Araneae: Lycosidae)

3

4 Camille Ameline (corresponding author), ORCID ID: 0000-0001-6892-2819

5 Université de Rennes 1, EA 7316, 263 Avenue du Général Leclerc, CS 74205, 35042 Rennes

6 Cedex, France

7 Current address: University of Basel, Zoological Institute, Evolutionary Biology, Vesalgasse

8 1, 4051 Basel, Switzerland

9 cameline8@gmail.com, camille.ameline@unibas.ch, phone: +41(0)61 2070372

10

Toke Thomas Høye, ORCID ID: 0000-0001-5387-3284

Department of Bioscience and Arctic Research Centre, Aarhus University, Grenåvej 14, DK8410 Rønde, Denmark

Joseph James Bowden, ORCID ID: 0000-0003-0940-4901

Arctic Research Centre, Aarhus University, Ny Munkegade 114, bldg. 1540, DK-8000 Aarhus C, Denmark

Current address: Canadian Forest Service - Atlantic Forestry Centre, Corner Brook, NL, Canada, 26 University Drive, PO Box 960, A2H 6J3

Rikke Reisner Hansen

Arctic Research Centre, Aarhus University, Ny Munkegade 114, bldg. 1540, DK-8000 Aarhus C, Denmark

Oskar Liset Pryds Hansen

Arctic Research Centre, Aarhus University, Ny Munkegade 114, bldg. 1110, DK-8000 Aarhus C, Denmark

Natural History Museum Aarhus, Wilhelm Meyers Allé 210, Universitetsparken, DK-8000 Aarhus C.

Charlène Puzin

Université de Rennes 1, EA 7316, 263 Avenue du Général Leclerc, CS 74205, 35042 Rennes Cedex, France

Philippe Vernon

Université de Rennes 1, CNRS, UMR 6553 ECOBIO, Station Biologique de Paimpont, 35380 Paimpont, France

Julien Pétillon

Université de Rennes 1, CNRS, UMR 6553 ECOBIO, 263 Avenue du Général Leclerc, 35042 Rennes Cedex, France 
Environmental gradients can help us comprehend the range of adaptations or plasticity that a given species can exhibit in response to climatic change. In this study, we assessed the response in female body size, clutch size and egg volume to elevational gradients in closely related wolf spiders. We measured these traits in Pardosa glacialis, $P$. hyperborea, $P$. furcifera and $P$. palustris, collected along elevational gradients across six sites in Arctic and sub-Arctic regions (four sites in Greenland, one in Iceland and one in the Faroe Islands), although not all species were found at all sites. Body size and reproductive traits did not vary with elevation in a consistent manner among species although smaller species were more sensitive to the gradients. The positive relationship between body size and clutch size was most pronounced in the larger species, indicating that larger species are better able to translate favourable environmental conditions into a larger reproductive output. Our study illustrates that elevational gradients may not fully capture spatial variation in environmental conditions experienced by high latitude wolf spider species.

Keywords: Arctic environment, biometry, altitude, environmental gradients, Pardosa, cocoon.

\section{Introduction}

Life history traits are essential to determine the distribution of species and populations. In the Arctic, the relatively harsh environmental conditions can amplify biological phenomena witnessed in temperate regions, allowing us to observe changes in life history traits at smaller geographic scales (Berteaux et al. 2004, Duarte et al. 2012). For example, the same pattern of a given morphological trait might be visible along a shorter spatial gradient in the Arctic than in a temperate region. Because of this, the Arctic has become a major focus of ecological research in the context of climate change (Høye and Sikes 2013). Furthermore, warming is 
much stronger in the Arctic and at high elevations (Wang et al. 2016), and harsh

environmental conditions generally lead to resource limitation (Roff 2002), causing allocation trade-offs: the Arctic is resource-poor compared to temperate regions (Bowden and Buddle 2012b; Ameline et al. 2017). Resource limitation is known to drive evolutionary strategies, such as the K, $\mathrm{r}$ and A strategies (Greenslade 1983, Holm 1988). Individuals and populations are confronted with multiple environmental constraints along spatial gradients, like latitude or elevation. Abiotic factors such as temperature and growing season length vary across these gradients (Conover and Present 1990), while biotic factors like predation risk also change (Roslin et al. 2017). Changes in elevation also trigger gradients in temperature lapse rate, short-wave radiation input, partial pressure of respiratory gases, precipitation (and related humidity), turbulence and wind speed (Hodkinson 2005, Sundqvist et al. 2013). These changes can occur more abruptly across smaller spatial scales in elevation gradients compared to latitude gradients. Due to the rapid rate at which climate change is affecting northern ecosystems, it is essential to understand how populations respond to such climatic constraints (Ohlberger 2013). By combining latitudinal and elevational gradients, it may be possible to identify the environmental controls of life history trait variations.

Body size is a key trait related to the life history of individuals and can influence a broad range of factors from competition for mates to the amount of resources that an individual can allocate to reproduction. Body size variation along spatial gradients has been studied intensively, as body size is 'a continuously varying trait dependent on a variety of factors operating at different stages in an individual's life' (Chown and Gaston 2010). The conditions under which an organism has developed are reflected in its body size. This makes body size a good labile trait for assessing phenotypic plasticity in response to climatic variability. Since the 19th century, many hypotheses were proposed as 'ecological rules' to try to explain observed variations of body size along geographical gradients. The most famous one is 
Bergmann's rule which proposes that the body size of endotherms increases with latitude (e.g. Atkinson and Sibly 1997; Blackburn et al. 1999; Shelomi 2012). This rule states that a larger organism has a reduced surface to volume ratio, which minimizes heat loss. It has since been extended to include patterns in body size of ectotherms across latitudinal and elevational gradients (Blanckenhorn and Demont 2004; Chown and Gaston 2010; Shelomi 2012, spiders: Entling et al. 2010). Bergmann's rule was set as a temperature effect while the converse Bergmann's rule has been set as a season length effect (Sheridan and Bickford 2011). This extension to the rule supposes that shorter seasons at higher latitudes reduce the foraging period, resulting in a limited growth and development period (Mousseau 1997). A gradient of decreasing body size towards the poles should then be observable (Blanckenhorn and Demont 2004). Another rule, the countergradient variation is also linked to seasonal limitations and assumes that populations at higher latitudes would compensate for the reduced season length by growing faster (Conover and Present 1990). It is still a controversial subject and there is no clear explanation as to why body size increases or decreases when an organism is exposed to low temperatures (Angilletta et al. 2004). Studies on ectotherms showed an increased body size of animals reared at lower temperatures, revealing a greater decrease of developmental rate than of growth rate (Forster et al. 2011a, b). This phenomenon is termed the ‘developmental temperature-size rule’ or TSR (Atkinson 1994). There could also be a tradeoff between fecundity and a delayed maturity. Delayed maturation leads to a larger body size and an increase in fecundity (Roff 2002).

Wolf spiders (Lycosidae) are found in high densities in the Arctic (e.g. Bowden and Buddle 2012b). Among this group, female Pardosa carry their egg cocoons, or egg sacs, attached to their spinnerets, which allows for specimen-specific measurement of fecundity and quality of the offspring (e.g. Pétillon et al. 2011). Clutch size has previously been considered a proxy for fecundity (e.g. Bowden et al. 2013), as species of Pardosa in the Arctic are generally thought 
to produce only one clutch per lifetime and not to overwinter after reproduction (semelparous species, Bowden and Buddle 2012a). Consequently, we expect season length to play a larger role than temperature in the development of these spiders, compared to other species that reproduce multiple times in their lifetime or during multiple seasons. Høye et al. (2009) found in P. glacialis that body size varied mostly in relation to season length (timing of snowmelt). Since clutch size is related to body size (Pétillon et al. 2009; Puzin et al. 2011; Hein et al. 2015, 2018), we also expect season length to have a greater impact on reproductive traits in Pardosa species. Egg volume commonly serves as a proxy for offspring quality, as bigger eggs result in bigger and fitter offspring (Hendrickx and Maelfait 2003).

In this study, we measure body size and reproductive traits along elevational gradients at six sites in Arctic and sub-Arctic areas. We aim to determine if closely related species (Pardosa spp.) display similar patterns in life history traits along these gradients. We test the following hypotheses: (1) As we expect season length to play a greater role than temperature in development, body size decreases with elevation, following a converse Bergmann's cline (spiders: latitude: Puzin et al. 2014, elevation: Høye and Hammel 2010; Bowden et al. 2013; Hein et al. 2015). This is the case in most terrestrial univoltine arthropods (Horne et al. 2015), and we expect similar constraints on the Pardosa species we studied. (2) As resources are more limited in high elevation, clutch size decreases with elevation; provided that female body size also decreases with elevation, as we know that reproductive outputs are linked to body size (Bowden et al. 2013); and egg volume increases with elevation, revealing a quantity/quality trade-off in female fecundity in response to harsh environmental conditions (Hendrickx et al. 2003; Puzin et al. 2011). 


\section{Material and Methods}

135

136

137

138

139

140

141

142

143

144

145

146

147

148

149

150

151

152

153

154

155

156

157

158

\section{Collected species}

We collected four different species belonging to the genus Pardosa (Araneae, Lycosidae): $P$. hyperborea (Thorell 1872), P. palustris (Linnaeus 1758), P. glacialis (Thorell 1872) and P. furcifera (Thorell 1875), with contrasted habitat preferences, but most are thought to produce only one clutch per lifetime (semelparous species) (see Table 1 for life cycle information and Online Resource 1 for habitat data). Most Arctic and sub-Arctic Pardosa species have multiyear life cycles (at least two years), overwintering as young juveniles in their first winter and as sub-adults in their second winter (Edgar 1971; Pickavance 2001; Høye et al. 2009; Bowden and Buddle 2012b). Growing season spans from May-June to August-September depending on the species, location and sex (Table 1).

We collected P. hyperborea at three different sites in Greenland (Kobbefjord, Godthaabsfjord and Narsarsuaq), P. palustris in Iceland and in the Faroe islands, P. glacialis in Greenland (Zackenberg) and P. furcifera in Greenland (Kobbefjord) (Figure 1, Table 2). As we only collected three individuals of $P$. furcifera at high elevation, we did not test the effect of elevation on this species (Table 2). We hand collected over a small period of time (maximum of two weeks, Table 2) at each site. We collected thirty females with egg sacs at each point when possible (Table 2) within a relatively small area ('collection point'; $<50 \mathrm{~m}^{2}$ ) and preserved them in $70 \%$ ethanol. We sampled either in 50 meter a.s.l. intervals along an elevational gradient or at low versus high elevations, depending on the elevational distribution of the species (Table 2, Online Resource 2). Lycosidae in boreal and Arctic regions are nonweb building species (Marusik 2015). We believe that no migration was possible between collection points as they are separated by several kilometers, except for Kobbefjord ( $P$. hyperborea) and Zackenberg (P. glacialis), where spiders were collected along a two kilometer regular slope, i.e. every 500 m (Online Resource 2). 


\section{Laboratory measurements}

161 We estimated body size, fecundity and egg quality by prosoma width, clutch size, and mean

162 egg volume, respectively in the laboratory with a EUROMEX trinocular stereomicroscope 45X, magnification 25X, connected with a CMEX5000 camera. Pictures and measurements were taken with the software EUROMEX ImageFocus v3.0. For each individual, we measured the following attributes: tibia length of leg I pair, length and width of the prosoma, clutch size (number of eggs) and mean length and width of ten randomly subsampled eggs (see Online Resource 3 for pictures). We calculated mean egg volume using the formula:

Volume $=\frac{\pi}{6} \times$ length $\times$ width $^{2}$ following Hendrickx and Maelfait (2003). We divided embryonic stages into six categories: I: only cells are visible; II: legs are visible; III: the prosoma is developed; IV: the prosoma is hatched and no measurement is possible; V: the postembryonic individual is hatched within the egg sac; VI: the postembryonic individual has emerged from the egg sac (Online Resources 3 and 4). We used this last stage when the collection in ethanol made the postembryonic individuals ( $1^{\text {st }}$ instar larvae) exit the egg sac. Since we always collected a female with an intact egg sac, we assume not to have lost any individuals. A large proportion of the egg sacs (34 \% of all individuals) contained eggs, which had hatched when dissected (stages IV to VI). This bias is however difficult to avoid given 177 that sampling cannot be done with exact synchrony in the field. Due to the variation in the 178 development of eggs, we considered mean egg volume as a less reliable trait than clutch size, and refrained from using a global variable connecting clutch size and mean egg volume. We did all measurements on all four species, with a total of 775 females. Of the 775 individuals in total, 14 cocoons (13-low, 1-high elevation) of $P$. hyperborea were found to be parasitized from the Narsarsuaq (South Greenland) site. No parasitism was found in the other three species. This represented an incidence of $1.8 \%$ parasitism for all data combined, but $18 \%$ of the population of 
P. hyperborea collected from the low site at Narsarsuaq. Teneral adults were identified as Gelis sp. (Hymenoptera, Ichneumonidae, Cryptinae) (Online Resource 3, Figures 2.1 to 2.3).

\section{Analyses}

In order to get a representative measurement of body size, correlations were assessed between all of our size measurements. Prosoma width was correlated with prosoma length, left tibia length and right tibia length by 99\% (Pearson correlation test, $t=170.0, d f=763, p<$ 0.0001), 95\% $(t=83.8, d f=738, p<0.0001)$ and 95\% $(t=84.9, d f=732, p<0.0001)$, respectively. Hence, we chose to use prosoma width as a proxy of body size (as used in Jakob et al. 1996). Henceforth we refer to prosoma width as body size if not stated otherwise. First, the effects of elevation on body size and on reproductive traits were assessed. Sampling differences (Table 2) necessitated that we tested for the effects of elevation on species and sites, separately. Second, the effect of body size on reproductive traits was assessed for our entire data set and for each species separately. All measurements were normally distributed (Online Resource 5). Linear models were applied, LLSR (Linear Least Squares Regression) in the case of continuous explanatory variables, ANCOVA (Analysis of Covariance) in the case of both continuous and categorical explanatory variables and factors. When testing for the effect of elevation, we included collection point as a random effect to avoid site-specific effects using linear mixed models (function 'Imer' in R package 'Ime4', Bates et al. 2015). For testing the effects of elevation on reproductive traits, we always include female body size as a covariate. Significance of explanatory variables and factors was tested via an ANOVA test using type III sums of squares (package 'car’: Fox and Weisberg 2011), i.e., without taking the order of the explanatory variables/factors into account. Finally, normal distribution of the residuals of the model was tested through a distribution histogram and a quantilequantile plot. All models are presented in Tables 3 and 4. All means are presented with 
standard error (package ‘RVAideMemoire’: Hervé 2015) and all statistics were conducted using the R environment for statistical computing v. 3.3.2 (R Development Core Team 2016).

\section{Results}

\section{The effect of elevation on body size and reproductive traits}

Mean body size (prosoma width) of Pardosa hyperborea, P. palustris, P. glacialis and P. furcifera were $1.85 \pm 0.006 \mathrm{~mm}(n=465), 2.17 \pm 0.013 \mathrm{~mm}(n=90), 2.60 \pm 0.012 \mathrm{~mm}(n=$ $151)$ and $3.05 \pm 0.020 \mathrm{~mm}(n=59)$, respectively. Mean body size of $P$. hyperborea was larger in Kobbefjord with mean sizes of $1.95 \pm 0.0096 \mathrm{~mm}(n=178), 1.80 \pm 0.0071 \mathrm{~mm}(n=166)$ in Godthaabsfjord and $1.78 \pm 0.0077 \mathrm{~mm}(n=123)$ in Narsarsuaq, (ANOVA, $p<0.0001$, TukeyHSD test, $p<0.0001)$. Elevation had no effect on the body size of P. glacialis ( $p=$ 0.56) or of $P$. hyperborea in Godthaabsfjord $(p=0.72)$ or Kobbefjord $(p=0.44$, Table 3 , Figure 2a). There was a positive effect of elevation on body size for $P$. hyperborea in Narsarsuaq ( $p=0.049$, Table 3, Figure 2a). At the lower elevation, mean body size was 1.77 $\pm 0.009 \mathrm{~mm}(n=52)$ compared to $1.80 \pm 0.013 \mathrm{~mm}(n=71)$ at the higher elevation. Similarly, elevation had a positive effect on $P$. palustris body size $(p=0.0092$, Table 3 , Figure 2a): mean body size was $2.09 \pm 0.019 \mathrm{~mm}(n=30)$ at the lower elevation compared to $2.23 \pm$ $0.023 \mathrm{~mm}(n=30)$ at the higher elevation.

Elevation did not have an effect on clutch size for P. glacialis $(p=0.40)$, $P$. hyperborea in Godthaabsfjord ( $p=0.19)$ and Narsarsuaq $(p=0.065)$ and for $P$. palustris $(p=0.12)$ (Table 3, Figure 2b). For $P$. hyperborea in Kobbefjord, elevation did have a negative effect on clutch size ( $p=0.00039$, Table 3, Figure $2 b)$ : clutch size at the lowest elevation was $39 \pm 1(n=60)$ 
compared to $27 \pm 1(n=30)$ at the highest elevation. Elevation did not have any effect on mean egg volume for all species and sites: P. glacialis $(p=0.46), P$. hyperborea in Godthaabsfjord ( $p=0.39$ ), Kobberfjord $(p=0.73)$ nor $P$. palustris $(p=0.96)$ (Table 3, Figure 2c). This effect was not tested for $P$. hyperborea in Narsarsuaq as only 5 females carried unhatched eggs.

\section{The effect of body size on reproductive traits}

There was an effect of species $(p<0.0001)$, a positive effect of female body size $(p<0.0001)$ and an effect of their interaction on clutch size $(p<0.0001)$ (Table 4$)$, meaning that the effect differed between species. Specifically, the positive effect of female body size on clutch size was stronger for larger species (Figure 3, regression slopes: P. hyperborea: $33.04 \pm 2.26, P$. palustris: $47.53 \pm 7.28$, P. glacialis: $82.93 \pm 7.20$, P. furcifera: $81.02 \pm 12.77)$. There was no effect of species ( $p=0.33$ ), body size $(p=0.15)$ nor their interaction $(p=0.44)$ on mean egg volume (Table 4), meaning that mean egg volume varied independently from female body size.

\section{Discussion}

\section{Body size patterns along elevational gradients among sites and species}

For Pardosa palustris and P. hyperborea at one collection site, female body size increased between low and high elevation, however female size in $P$. glacialis and $P$. hyperborea at the two other sites did not respond to elevation. Hence, it appears that body size of P. palustris and $P$. hyperborea are more sensitive to elevation than $P$. glacialis and that the smaller species are more sensitive to elevational gradients. This result contradicts our first hypothesis, 
which was that spiders would be smaller at higher elevations. Similarly, Hein et al. (2015) did not find any general body size pattern along elevational gradients. Conversely, Høye and Hammel (2010) did find a decrease in body size on female P. glacialis at high elevation. Body size patterns along elevation could be species-specific (Høye and Hammel 2010; Bowden et al. 2013) or may depend on the body size of the species in question (Blanckenhorn and Demont 2004). Such variation could arise from the combined effect of life-history traits, habitat, latitude and movement as we discuss below.

We observed different patterns among species that can be triggered by differences in lifehistory traits (see Table 1). We know that $P$. glacialis individuals take multiple years to reach adult size (Høye et al. 2009 and Marusik 2015: Table 1), but smaller species may require less time to reach adulthood. We assume that the larger species $P$. furcifera also has a longer lifecycle, although this is not documented. These species could thus increase their development time to be able to grow larger, trading delayed maturity for a larger body size, in spite of the possible disadvantages of a longer development time. This suggests that larger Arctic Pardosa species might have developed a distinct strategy to tackle environmental challenges. Ecological trade-offs have also been described in temperate forest wolf spiders, e.g. risk of freezing vs. ability to grow at low temperatures (Whitney et al. 2014). However, phylogeography (Gür 2010), adaptation (Stillwell 2010) or biological interactions (e.g., Callaway et al. 2002) might also help explain size responses to elevation.

Temperature is known to decrease approximately $0.5-0.55^{\circ} \mathrm{C}$ with an increase of $100 \mathrm{~m}$ in elevation (Marshall et al. 2007), while growing season becomes shorter with elevation (O’Neill et al. 2015). We know that climate change is stronger in the Arctic and at high elevations (Wang et al. 2016), which causes earlier snowmelt and thus relatively longer growing seasons (Semmens et al. 2013). It is estimated that a $1^{\circ} \mathrm{C}$ increase in mean annual temperature would result in a range change of $\sim 167 \mathrm{~m}$ in elevation and $145 \mathrm{~km}$ in latitude 
(Jump et al. 2009). It has been shown in a large variety of terrestrial arthropods that larger species are less affected by warming than smaller species (Forster et al. 2012). This could allow large Pardosa species to become even larger in response to climate change. Intraspecifically, it remains difficult to predict the effects of increasing temperatures along elevational gradients, as elevation-body size clines often appear to deviate from temperaturebody size cline measured in the laboratory (Horne et al. 2018).

Local habitat variation could also drive the patterns in body size along elevational gradients, as habitats change rapidly over elevational gradients. Indeed, body size trends in similar groups have been shown to be affected by local habitat variation (Høye et al. 2009; Bowden et al. 2015). Previous studies of Arctic spider assemblages have also suggested that habitat is a key determinant in species turnover across elevation in these ecosystems (Bowden and Buddle 2010, wet vs. dry habitats: Ernst et al. 2016; Hansen et al. 2016b; Cameron and Buddle 2017; Høye et al. 2018).

In our study, we could not disentangle the effect of species from that of latitude because all species were not present at all sampling sites, and this is why we ran separate models for each species and sites. As a consequence, latitudinal effects could mask or supress elevational effects. We found distinct patterns of body size and reproductive traits along separate elevational gradients in the same species ( $P$. hyperborea) sampled at nearby sites (the Kobbefjord population was sampled between $40 \mathrm{~km}$ and $100 \mathrm{~km}$ away from the Godthaabsfjord populations during the same period in the same year (Table 2), which suggests that latitude is not the primary factor that affects elevational patterns in our study species. We suggest that variation in microhabitat influenced our results, while inter-annual climatic variation could also have played a role. We found our largest species, $P$. furcifera, in South Greenland, although only three individuals were collected at high elevations. Further sampling of this species or other large species such as $P$. groenlandica are necessary to test 
the hypothesis that larger species are less sensitive to environmental changes, regardless of latitude. We sampled P. glacialis in Zackenberg (North-East Greenland), although it is also found at lower latitudes in South-West Greenland but at low abundances and only at high elevations (Hansen et al. 2016a). Adaptation to harsher climatic conditions at higher latitudes could also explain why we do not observe body size nor reproductive traits responses to elevation in P. glacialis.

Some Pardosa species have been shown to be able to actively migrate to maximum distances of 500 m per day (P. pullata, P. prativaga, Richter et al. 1971), $50 \mathrm{~m}$ in $10 \mathrm{~min}$ (P. lapidicina, Morse 2002), 280 m per day (P. monticola in moss dunes, Bonte et al. 2003), or 40-150 m over several months (P. pullata, $P$. chelata, Hallander 1967). We know that wolf spiders are able to migrate in response to environmental cues (Kraus and Morse 2005), and such shifts to suitable microhabitats may constitute a protective behaviour (Schaefer 1977). Since we do observe a pattern of body size in Kobbefjord in $P$. hyperborea, we suppose that migration does not play a significant role there. $P$. glacialis was collected along an elevational gradient of just 200 meters as well, but we do not observe a pattern of body size, so perhaps this environmental gradient was not sufficient to elicit an effect in this species.

\section{Interspecific differences in reproductive traits responses to elevation}

We found that clutch size and egg volume varied independently of elevation for $P$. glacialis and $P$. palustris while for $P$. hyperborea in Kobbefjord, clutch size decreased with elevation, but egg volume did not show any pattern. Similarly, Hein et al. (2018) found no variation of the eggs size/number trade-off in P. palustris along an elevational gradient. Our results show that $P$. hyperborea responded more strongly to elevation than the other two species. This supports our hypothesis of increased sensitivity of smaller Pardosa species to environmental changes, since $P$. hyperborea was the smallest species we collected. The absence of a trend 
between egg volume and body size can also indicate that the volume or mass of individual eggs is influenced more by a combination of body condition and environmental factors than clutch size (e.g. Bowden and Buddle 2012b). As egg volume does not vary along elevational gradients, it appears unnecessary for the eggs to be larger in colder environments.

\section{Interspecific variation in the relationship between body size and clutch size}

For all the species we studied, clutch size increased with body size, while egg volume varied independently of body size. This shows that intraspecifically, larger individuals could increase their fecundity more efficiently than smaller individuals. It has been shown among arthropods that clutch size generally increases with body size (Fox and Czesak 2000), including wolf spiders (Pétillon et al. 2009; Puzin et al. 2011; Hein et al. 2015, 2018). This emphasizes that a larger body size is beneficial for females because it enables them to increase their fecundity and ultimately their fitness.

From an interspecific point of view, the larger the species, the higher the rate at which clutch size increases with body size. Hence, larger species could increase their fecundity more efficiently than smaller species. According to the Metabolic Theory of Ecology (MTE), having a larger body size allows one to retain more energy because it is processed slower (Brown et al. 2004). This energy can thus be invested in a higher, albeit usually delayed reproductive output compared to smaller species. Within species, this theory can also explain why larger individuals can invest more in their reproductive output. Here, the reproductive output is associated with clutch size while egg volume is associated with the quality of offspring.

Our observation that egg volume was not well predicted by body size in wolf spiders mirrors findings by others (Brown et al. 2003; Hendrickx and Maelfait 2003; Hein et al. 2015). 
Indeed, investment in individual egg mass or volume does appear to be better explained by body condition than body size in this group (e.g., Bowden and Buddle 2012b).

\section{Conclusion}

We set out to assess the impact of environmental variation, employed through the use of elevational gradients, on body size and reproductive traits in Arctic wolf spiders. Due to the relative harshness of the environmental conditions in this region, we expected that elevational gradients would serve as local seasonal and temperature gradients. We found that smaller species at the respective sites showed more sensitivity to environmental changes. Second, intra- and interspecifically, larger individuals could increase their fecundity more efficiently than smaller individuals/species. Together, these results suggest that large body size is advantageous in the Arctic environment for these species. Third, it appears that females do not produce larger eggs at higher elevations. This could be explained by the fact that the high variability of alpine microclimatic conditions makes it possible for spiders to find suitable conditions even at higher elevations. Our results also show that there are no large-scale general patterns in species-specific responses to environmental changes, and that microclimatic conditions along with inter-annual climatic variation probably play a crucial role. We emphasize the need for further studies to measure, along with large-scale gradients, local environmental variables such as soil moisture, temperature, shrub dominance, snow-cover and growing season length.

\section{Acknowledgments}

This work was part of the SPACEWOLF project (Spatial gradients in physiological adaptation and life history traits of Arctic wolf spiders) led by Julien Pétillon and Philippe 
Vernon, and funded by INTERACT: International Network for Terrestrial Research and Monitoring in the Arctic. Cyril Courtial helped sample in Kobbefjord. Karina Fisker collected the samples in Iceland; Ana Luisa Machado and Mónica J.B. Amorim helped sample in the Faroe Islands. Parasitoids were identified by Claire Villemant, UMR 7205 Institut de Systématique, Évolution, Biodiversité, MNHN. We thank three anonymous reviewers for providing insightful comments on this work.

\section{Conflict of Interest: The authors declare that they have no conflict of interest.}

\section{References}

Ameline C, Puzin C, Bowden JJ, Lambeets K, Vernon P, Pétillon J (2017) Habitat specialization and climate affect arthropod fitness: a comparison of generalist vs. specialist spider species in Arctic and temperate biomes. Biol J Linn Soc 121:592-599

Angilletta MJ, Steury TD, Sears MW (2004) Temperature, growth rate, and body size in ectotherms: fitting pieces of a life-history puzzle. Integr Comp Biol 44:498-509

Atkinson D (1994) Temperature and organism size - a biological law for ectotherms? Adv Ecol Res 25:1-58 Atkinson D, Sibly RM (1997) Why are organisms usually bigger in colder environments? Making sense of a life history puzzle. Trends Ecol Evol 12:235-239

Bates D, Maechler M, Bolker B, Walker S (2015) Fitting linear mixed-effects models using lme4. J Stat Softw $67: 1-48$

Berteaux D, Réale D, McAdam AG, Boutin S (2004) Keeping pace with fast climate change: Can Arctic life count on Evolution? Integr Comp Biol 44: 140-151

Blackburn TM, Gaston KJ, Loder N (1999) Geographic gradients in body size: a clarification of Bergmann's rule. Divers Distrib 5:165-174 
Blanckenhorn WU, Demont M (2004) Bergmann and converse Bergmann latitudinal clines in arthropods: two ends of a continuum? Integr Comp Biol 44:413-424

Bonte D, Lens L, Maelfait J-P, Hoffmann M, Kuijken E (2003) Patch quality and connectivity influence spatial dynamics in a dune wolfspider. Oecologia 135:227-233

Bowden JJ, Buddle CM (2010) Spider assemblages across elevational and latitudinal gradients in the Yukon Territory, Canada. Arctic 63:261-272

Bowden JJ, Buddle CM (2012a) Egg sac parasitism of Arctic wolf spiders (Araneae: Lycosidae) from northwestern North America. J Arachnol 40:348-350

Bowden JJ, Buddle CM (2012b) Life history of tundra-dwelling wolf spiders (Araneae: Lycosidae) from the Yukon Territory, Canada. Can J Zoolog 90:714-721

Bowden JJ, Hansen RR, Olsen K, Høye TT (2015) Habitat-specific effects of climate change on a low-mobility Arctic spider species. Polar Biol 38:559-568

Bowden JJ, Høye TT, Buddle CM (2013) Fecundity and sexual size dimorphism of wolf spiders (Araneae: Lycosidae) along an elevational gradient in the Arctic. Polar Biol 36:831-836

Brown CA, Sanford BM, Swerdon RR (2003) Clutch size and offspring size in the wolf spider Pirata sedentarius (Araneae, Lycosidae). J Arachnol 31:285-296

Brown JH, Gillooly JF, Allen AP, Savage VM, West GB (2004) Toward a metabolic theory of ecology. Ecology $85: 1771-1789$

Buddle CM (2000) Life history of Pardosa moesta and Pardosa mackenziana (Araneae, Lycosidae) in central Alberta, Canada. J Arachnol 28:319-328

Callaway RM, Brooker RW, Choler P, Kikvidze Z, Lortie CJ, Michalet R, Paolini L, Pugnaire FI, Newingham B, Aschehoug ET, Armas C, Kokidze D, Cook BJ (2002) Positive interactions among alpine plants increase with stress. Nature 417:844-848

Cameron ER, Buddle CM (2017) Seasonal change and microhabitat association of Arctic spider assemblages (Arachnida: Araneae) on Victoria Island (Nunavut, Canada). Can Entomol 149:357-371

Chown SL, Gaston KJ (2010) Body size variation in insects: a macroecological perspective. Biol Rev 85:139-169 Conover DO, Present TM (1990) Countergradient variation in growth rate: compensation for length of the growing season among Atlantic silversides from different latitudes. Oecologia 83:316-324 
431

432

433

434

435

436

437

438

439

440

Dondale CD, Redner JH (1990) The insects and arachnids of Canada. Part 17. The wolf spiders, nurseryweb spiders, and lynx spiders of Canada and Alaska (Araneae: Lycosidae, Pisauridae, and Oxyopidae). Canadian Department of Agriculture Publications, Ottawa

Duarte CM, Lenton TM, Wadhams P, Wassmann P (2012) Abrupt climate change in the Arctic. Nat Clim Change 2:60-62

Edgar WD (1971) The life-cycle, abundance and seasonal movement of the wolf spider, Lycosa (Pardosa) lugubris, in Central Scotland. J Anim Ecol 40:303-322

Entling W, Schmidt-Entling MH, Bacher S, Brandl R, Nentwig W (2010) Body size-climate relationships of European spiders. J Biogeogr 37:477-485

Ernst CM, Loboda S, Buddle CM (2016) Capturing northern biodiversity: diversity of arctic, subarctic and north boreal beetles and spiders are affected by trap type and habitat. Insect Conserv Diver 9:63-73

Fick SE, Hijmans RJ (2017). Worldclim 2: New 1-km spatial resolution climate surfaces for global land areas. Int J Climatol

Forster J, Hirst AG, Atkinson D (2011a) How do organisms change size with changing temperature? The importance of reproductive method and ontogenetic timing. Funct Ecol 25: 1024-1031

Forster J, Hirst AG, Woodward G (2011b) Growth and development rates have different thermal responses. Am Nat 178: 668-678

Forster J, Hirst AG, Atkinson D (2012) Warming-induced reductions in body size are greater in aquatic than terrestrial species. PNAS 109:19310-19314

Fox CW, Czesak ME (2000) Evolutionary ecology of progeny size in arthropods. Annu Rev Entomol 45:341-369

Fox J, Weisberg S (2011) Package car. An $\{$ R $\}$ Companion to applied regression, Second Edition. Thousand Oaks CA: Sage.

Gür H (2010) Why do Anatolian ground squirrels exhibit a Bergmannian size pattern? A phylogenetic comparative analysis of geographic variation in body size. Biol J Linn Soc 100:695-710

Greenslade PJM (1983) Adversity selection and the habitat template. Am Nat 122:352-365

Hallander H (1967) Range and movements of the wolf spiders Pardosa chelata (O. F. Müller) and P. pullata (Clerck). Oikos 18:360-364

Hammel JU, Nickel M (2008) Pardosa hyperborea (Araneae: Lycosidae): a first report from Disko Island (West Greenland), with remarks on the biogeography of the species. Ent Meddr 76:41-47 
Hansen RR, Hansen OLP, Bowden JJ, Normand S, Bay C, Sørensen JG, Høye TT (2016a) High spatial variation in terrestrial arthropod species diversity and composition near the Greenland ice cap. Polar Biol 39:22632272

Hansen RR, Hansen OLP, Bowden JJ, Treier UA, Normand S, Høye TT (2016b) Meter scale variation in shrub dominance and soil moisture structure Arctic arthropod communities. PeerJ 4:e2224

Hein N, Brendel MR, Feilhauer H, Finch O-D, Löffler J (2018) Egg size versus egg number trade-off in the alpine-tundra wolf spider, Pardosa palustris (Araneae: Lycosidae). Polar Biol 41:1607-1617

Hein N, Feilhauer H, Löffler J, Finch O-D (2015) Elevational variation of reproductive traits in five Pardosa (Lycosidae) species. Arct Antarct Alp Res 47:473-479

Hendrickx F, Maelfait J-P (2003) Life cycle, reproductive patterns and their year-to-year variation in a field population of the wolf spider Pirata piraticus (Aranea, Lycosidae). J Arachnol 31:331-339

Hendrickx F, Maelfait J-P, Speelmans M, Van Straalen NM (2003) Adaptive reproductive variation along a pollution gradient in a wolf spider. Oecologia 134:189-194

Hervé M (2015) RVAideMemoire: Diverse basic statistical and graphical functions. R package version 0.9-45-2. Available at http://CRAN.R-project.org/package=RVAideMemoire

Hodkinson ID (2005) Terrestrial insects along elevation gradients: species and community responses to altitude. Biol Rev 80:489-513

Holm E (1988) Environmental restraints and life strategies: a habitat templet matrix. Oecologia 75:141-145

Horne CR, Hirst AG, Atkinson D (2015) Temperature-size responses match latitudinal-size clines in arthropods, revealing critical differences between aquatic and terrestrial species. Ecol Lett 18:327-335

Horne CR, Hirst AG, Atkinson D (2018) Insect temperature-body size trends common to laboratory, latitudinal and seasonal gradients are not found across altitudes. Funct Ecol 32:948-957

Høye TT, Bowden JJ, Hansen OLP, Hansen RR, Henriksen TN, Niebuhr A, Skytte MG (2018) Elevation modulates how Arctic arthropod communities are structured along local environmental gradients. Polar Biol 41:1555-1565

Høye TT, Hammel JU, Fuchs T, Toft S (2009) Climate change and sexual size dimorphism in an Arctic spider. Biol Letters 5:542-544

Høye TT, Hammel J (2010) Climate change and altitudinal variation in sexual size dimorphism of arctic wolf spiders. Climate Res 41:259-265

Høye TT, Sikes DS (2013) Arctic entomology in the 21st century. Can Entomol 145:125-130 
Jakob EM, Marshall SD, Uetz GW (1996) Estimating fitness: a comparison of body condition indices. Oikos 77:61-67

Jump AS, Mátyás C, Peñuelas J (2009) The altitude-for-latitude disparity in the range retractions of woody species. Trends Ecol Evol 24:694-701

Kraus JM, Morse DH (2005) Seasonal habitat shift in an intertidal wolf spider: proximal cues associated with migration and substrate preference. J Arachnol 33:110-123

Marshall SJ, Sharp MJ, Burgess DO, Anslow FS (2007) Near-surface-temperature lapse rates on the Prince of Wales Icefield, Ellesmere Island, Canada: implications for regional downscaling of temperature. Int J Climatol 27:385-398

Marusik YM (2015) Aranea (Spiders). In: Böcher J, Kristensen N P, Pape T, Vilhelmsen L (ed) The Greenland Entomofauna: An identification manual of insects, spiders and their allies. Fauna Entomological Scandinavica. Brill, Leiden, vol 44, pp 666-703

Morse, D. H. 2002. Orientation and movement of wolf spiders Pardosa lapidicina (Araneae, Lycosidae) in the intertidal zone. J Arachnol 30:601-609

Mousseau TA (1997) Ectotherms follow the converse Bergmann’s rule. Evolution 51:630-632

O’Neill HB, Burn CR, Kokelj SV, Lantz TC (2015) 'Warm’ Tundra: Atmospheric and near-surface ground temperature inversions across an alpine treeline in continuous permafrost, western Arctic, Canada. Permafrost Periglac 26:103-118

Ohlberger J (2013) Climate warming and ectotherm body size - from individual physiology to community ecology. Funct Ecol 27:991-1001

Pétillon J, Lambeets K, Ract-Madoux B, Vernon P, Renault D (2011) Saline stress tolerance partly matches with habitat preference in ground-living wolf spiders. Physiol Entomol 36:165-172

Pétillon J, Puzin C, Acou A, Outreman Y (2009) Plant invasion phenomenon enhances reproduction performance in an endangered spider. Naturwissenschaften 96:1241-1246

Pickavance JR (2001) Life-cycles of four species of Pardosa (Araneae, Lycosidae) from the island of Newfoundland, Canada. J Arachnol 29:367-377

Puzin C, Acou A, Bonte D, Pétillon J (2011) Comparison of reproductive traits between two salt-marsh wolf spiders (Araneae, Lycosidae) under different habitat suitability conditions. Anim Biol 61:127-138 
521

Puzin C, Leroy B, Pétillon J (2014) Intra-and inter-specific variation in size and habitus of two sibling spider species (Araneae: Lycosidae): taxonomic and biogeographic insights from sampling across Europe. Biol J Linn Soc 113:85-96

R Development Core Team (2016) R: A language and environment for statistical computing Version 3.3.2. Vienna, Austria: R Foundation for Statistical Computing. http://www.R-project.org/

Richter, C. J. J., Den Hollander, J., \& Vlijm, L. (1971). Differences in breeding and motility between Pardosa pullata (Clerk) and Pardosa prativaga (L. Koch), (Lycosidae, Araneae) in relation to habitat. Oecologia, 327:318-327

Roff D (2002) Life history evolution. Sinauer Associates, Sunderland

Roslin T, Hardwick B, Novotny V, Petry WK, Andrew NR, Asmus A, Barrio IC, Basset Y, Boesing AL, Bonebrake TC (2017) Higher predation risk for insect prey at low latitudes and elevations. Science $356: 742-744$

Schaefer M (1977) Winter ecology of spiders (Araneida). Z Angew Entomol 83:113-134

Semmens KA, Ramage J, Bartsch A, Liston GE (2013) Early snowmelt events: detection, distribution, and significance in a major sub-arctic watershed. Environ Res Lett 8:014020

Shelomi M (2012) Where are we now? Bergmann’s rule sensu lato in insects. Am Nat 180:511-519

Sheridan JA, Bickford D (2011) Shrinking body size as an ecological response to climate change. Nat Clim Change 1:401-406

Stillwell RC (2010) Are latitudinal clines in body size adaptive? Oikos 119:1387-1390

Sundqvist MK, Sanders NJ, Wardle DA (2013) Community and ecosystem responses to elevational gradients: processes, mechanisms, and insights for global change. Annu Rev Ecol Evol S 44:261-280

Wang Q, Fan X, Wang M (2016) Evidence of high-elevation amplification versus Arctic amplification. Sci Rep 6:19219

Whitney TD, Philip BN, Harwood JD (2014) Tradeoff in two winter-active wolf spiders: increased mortality for increased growth. Entomol Exp Appl 153:191-198 
545 Table 1 Life cycle information currently known for the collected species. a: Bowden and Buddle 546 2012a; b: Pickavance 2001; c: Marusik 2015; d: Bowden and Buddle 2010; e: Hammel and Nickel 547 2008; f: Dondale and Redner 1990; g: Buddle 2000; h: inferred from related species in similar latitudes 548 e.g. Edgar 1971; i: Høye et al. 2009; j: Hein et al. 2018. ${ }^{*}$ We propose that $P$. furcifera could have a 549 similar life-span to $P$. glacialis, as they present similar sizes

550

\begin{tabular}{|c|c|c|c|c|c|}
\hline Species & Life cycle & Development season & Reproduction & Hatching period & Overwintering \\
\hline P. glacialis & $2-3$ years ${ }^{11}$ & $\begin{array}{l}\text { highest activity: mid-June to } \\
\text { late-July at high latitudes }{ }^{[d]} \\
\text { males and females: June to } \\
\text { August }{ }^{[f]}\end{array}$ & $\begin{array}{l}\text { one clutch per } \\
\text { lifetime }^{[a]}\end{array}$ & $\begin{array}{l}\text { egg sacs: July and } \\
\text { August }{ }^{[\mathrm{f}, \mathrm{i}} \text {, hatching: } \\
\text { August }{ }^{[i]}\end{array}$ & $\begin{array}{l}\text { one or two winters before maturation, } \\
\text { females are thought not to overwinter after } \\
\text { reproduction }[a, b] \\
\text { overwinters in soil cracks and under stones } \\
{[c]}\end{array}$ \\
\hline P. hyperborea & $\begin{array}{l}\text { 2-year life span, } \\
\text { inferred from } \\
\text { related species } \\
{[\mathrm{b}, \mathrm{g}]}\end{array}$ & 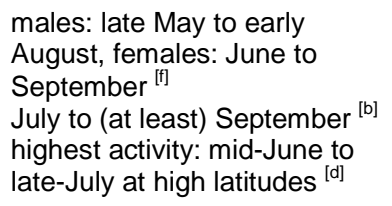 & $\begin{array}{l}\text { one clutch per } \\
\text { lifetime }^{[a]}\end{array}$ & $\begin{array}{l}\text { August to } \\
\text { September }{ }^{[b]} \\
\text { July }{ }^{[\mathrm{e}]} \\
\text { egg sacs observed } \\
\text { in July and August } \\
{ }_{[\mathrm{f}]}\end{array}$ & $\begin{array}{l}\text { one or two winters before maturation, } \\
\text { females are thought not to overwinter after } \\
\text { reproduction }{ }^{[a, b]}\end{array}$ \\
\hline P. furcifera & $\begin{array}{l}\text { 2-3 year life span, } \\
\text { inferred from } \\
\text { related species } \\
{[\mathrm{b}, \mathrm{g}]_{\star}}\end{array}$ & $\begin{array}{l}\text { males: mid-June to July, } \\
\text { females: mid-June to August } \\
\text { [f] } \\
\text { highest activity: mid-June to } \\
\text { late-July at high latitudes }{ }^{[d]}\end{array}$ & $\begin{array}{l}\text { one clutch per } \\
\text { lifetime }^{[a]}\end{array}$ & $\begin{array}{l}\text { egg sacs: July, } \\
\text { hatched: mid- } \\
\text { August }{ }^{[\mathrm{f}]}\end{array}$ & $\begin{array}{l}\text { one or two winters before maturation, } \\
\text { females are thought not to overwinter after } \\
\text { reproduction }{ }^{[a, b]}\end{array}$ \\
\hline P. palustris & $\begin{array}{l}\text { 2-3 year life } \\
\text { span, }^{[b, g, h, j]}\end{array}$ & May and June ${ }^{[f]}$ & $\begin{array}{l}\text { 1-3 clutches } \\
\text { per lifetime }\end{array}$ & egg sacs: June ${ }^{[f]}$ & $\begin{array}{l}\text { one or two winters before maturation, } \\
\text { females are thought not to overwinter after } \\
\text { reproduction }{ }^{[a, b, h]}\end{array}$ \\
\hline
\end{tabular}


552 Table 2 Sampling details of hand collections of Pardosa species. Temperature data was acquired

553 through BioClim (Fick and Hijmans 2017)

\begin{tabular}{|c|c|c|c|c|c|c|c|c|}
\hline Country & Area & $\begin{array}{l}\text { Latitude } \\
\text { (DD } \\
\text { WGS84) }\end{array}$ & $\begin{array}{l}\text { Longitude } \\
\text { (DD } \\
\text { WGS84) }\end{array}$ & $\begin{array}{l}\text { Tempe } \\
\text { rature } \\
\text { annual } \\
\text { range } \\
\left({ }^{\circ} \mathrm{C}\right)\end{array}$ & $\begin{array}{l}\text { Mean } \\
\text { temperat } \\
\text { ure of } \\
\text { warmest } \\
\text { quarter } \\
\left({ }^{\circ} \mathrm{C}\right) \\
\end{array}$ & $\begin{array}{l}\text { Date } \\
\text { (dd/mm/yyyy) }\end{array}$ & Species & $\begin{array}{l}\text { Elevation (m a.s.I.) } \\
\text { (sampling effort } n \text { ) }\end{array}$ \\
\hline \multirow{4}{*}{ Greenland } & Zackenberg & 74.467 & -20.566 & 32.3 & 2.3 & $05-12 / 08 / 2014$ & P. glacialis & $\begin{array}{l}20 \mathrm{~m}(30)^{\mathrm{v}}, 50 \mathrm{~m}(32), 100 \mathrm{~m} \\
(30)^{\mathrm{v}}, 150 \mathrm{~m}(30), 200 \mathrm{~m} \\
(30)^{\mathrm{v}}\end{array}$ \\
\hline & Kobbefjord & 64.117 & -51.350 & 23.0 & 4.6 & $05-10 / 07 / 2013$ & $\begin{array}{l}\text { P. hyperborea } \\
\text { P. furcifera }\end{array}$ & $\begin{array}{l}\text { Om (30x2), 50m (30), 100m } \\
(30), 150 m(30), 200 m(30) \\
0 m(30 \times 2)^{\star}, 200 m(3)^{\star}\end{array}$ \\
\hline & Godthaabsfjord & 64.144 & -51.474 & 22.8 & 5.1 & $15-29 / 07 / 2013$ & P. hyperborea & $\begin{array}{l}18 m(30)^{\mathrm{a}}, 20 \mathrm{~m}(22)^{\mathrm{a}}, 49 \mathrm{~m} \\
(30), 153 \mathrm{~m}(30)^{\star}, 402 \mathrm{~m} \\
(23), 678 \mathrm{~m}(30)\end{array}$ \\
\hline & Narsarsuaq & 61.183 & -45.371 & 24.8 & 9.0 & $24-31 / 07 / 2014$ & P. hyperborea & $\begin{array}{l}\text { 42-54m (71) }, 400-430 m \\
(51)^{v}\end{array}$ \\
\hline Iceland & Reykjavík & 64.525 & -21.880 & 16.2 & 9.8 & $06 / 2012$ & P. palustris & 3-40m (30), 390-410m (30) \\
\hline $\begin{array}{l}\text { Faroe } \\
\text { Islands }\end{array}$ & Tórshavn & 62.041 & -6.877 & 12.0 & 8.5 & $12-18 / 06 / 2012$ & P. palustris & $350 \mathrm{~m}(30)^{*}$ \\
\hline
\end{tabular}

554 DD: decimal degrees

$555{ }^{a}$ for models assessing elevation's effects on body size and reproductive traits, 30 individuals were picked randomly from the 18

$556 \mathrm{~m}$ pool and the $20 \mathrm{~m}$ pool.

557 * pools that were not used for models assessing elevation's effects on body size and reproductive traits.

558 v pools that were not used for the model assessing elevation's effects on mean egg volume due to variation in development

559 stages.

560 
561 Table 3 Models used to test the effects of elevation on body size and reproductive traits

\begin{tabular}{|c|c|c|c|c|c|c|c|c|}
\hline & & Initial model & Model & Response variable & Explanatory variables & B estimate (b) & SE & $p$ \\
\hline \multirow[t]{5}{*}{$\begin{array}{l}\text { Effect of elevation on body } \\
\text { size }\end{array}$} & for Pardosa glacialis & body size elevation + (1|site) & $L L S R$ & body size & elevation & $2.02 \times 10^{-4}$ & $4.54 \times 10^{-4}$ & 0.56 \\
\hline & for $P$. hyperborea in Godthaabsfjord & body size elevation + (1|site) & LLSR & body size & elevation & $1.53 \times 10^{-5}$ & $5.47 \times 10^{-5}$ & 0.72 \\
\hline & for P. hyperborea in Kobbefjord & body size elevation + (1|site) & LLSR & body size & elevation & $2.33 \times 10^{-4}$ & $3.62 \times 10^{-4}$ & 0.44 \\
\hline & for $P$. hyperborea in Narsarsuaq & body size elevation + (1|site) & LLSR & body size & elevation & $9.77 \times 10^{-5}$ & $8.14 \times 10^{-5}$ & 0.049 \\
\hline & for $P$. palustris in Iceland & body size elevation + (1|site) & LLSR & body size & elevation & $3.64 \times 10^{-4}$ & $3.75 \times 10^{-4}$ & 0.0092 \\
\hline \multirow[t]{10}{*}{$\begin{array}{l}\text { Effect of elevation on clutch } \\
\text { size }\end{array}$} & for P. glacialis & clutch size $\sim$ body size + elevation + (1|site) & ANCOVA & clutch size & body size & 81.74 & 7.44 & $<0.0001$ \\
\hline & & & & & elevation & 0.016 & 0.025 & 0.40 \\
\hline & for P. hyperborea in Godthsaabsfjord & clutch size $\sim$ body size + elevation + (1|site) & ANCOVA & clutch size & body size & 42.05 & 4.13 & $<0.0001$ \\
\hline & & & & & elevation & $3.50 \times 10^{-3}$ & $3.00 \times 10^{-3}$ & 0.19 \\
\hline & for $P$. hyperborea in Kobbefjord & clutch size $\sim$ body size + elevation + (1|site) & ANCOVA & clutch size & body size & 31.33 & 3.11 & $<0.0001$ \\
\hline & & & & & elevation & -0.072 & 0.013 & 0.00039 \\
\hline & for $P$. hyperborea in Narsarsuaq & clutch size $\sim$ body size + elevation + (1|site) & ANCOVA & clutch size & body size & 24.35 & 6.60 & 0.00015 \\
\hline & & & & & elevation & $6.30 \times 10^{-3}$ & $6.86 \times 10^{-3}$ & 0.065 \\
\hline & for $P$. palustris in Iceland & clutch size $\sim$ body size + elevation + (1|site) & ANCOVA & clutch size & body size & 66.72 & 9.39 & $<0.0001$ \\
\hline & & & & & elevation & -0.010 & $9.4 \times 10^{-3}$ & 0.12 \\
\hline \multirow[t]{8}{*}{$\begin{array}{l}\text { Effect of elevation on mean } \\
\text { egg volume }\end{array}$} & for $P$. glacialis & $\begin{array}{l}\text { mean egg volume } \sim \text { body size + elevation }+ \\
\text { (1|site) }\end{array}$ & ANCOVA & mean egg volume & body size & $1.07 \times 10^{-2}$ & $7.41 \times 10^{-2}$ & 0.80 \\
\hline & & & & & elevation & $5.77 \times 10^{-5}$ & $3.99 \times 10^{-4}$ & 0.46 \\
\hline & for $P$. hyperborea in Godthsaabsfjord & $\begin{array}{l}\text { mean egg volume } \sim \text { body size }+ \text { elevation }+ \\
\text { (1/site) }\end{array}$ & ANCOVA & mean egg volume & body size & $1.25 \times 10^{-2}$ & $4.11 \times 10^{-2}$ & 0.77 \\
\hline & & & & & elevation & $-3.15 \times 10^{-5}$ & $5.01 \times 10^{-5}$ & 0.39 \\
\hline & for $P$. hyperborea in Kobbefjord & $\begin{array}{l}\text { mean egg volume } \sim \text { body size + elevation + } \\
\text { (1/site) }\end{array}$ & ANCOVA & mean egg volume & body size & $-2.42 \times 10^{-2}$ & $2.50 \times 10^{-2}$ & 0.36 \\
\hline & & & & & elevation & $2.40 \times 10^{-5}$ & $8.26 \times 10^{-5}$ & 0.73 \\
\hline & for $P$. palustris in Iceland & $\begin{array}{l}\text { mean egg volume } \sim \text { body size }+ \text { elevation }+ \\
\text { (1|site) }\end{array}$ & ANCOVA & mean egg volume & body size & $-2.81 \times 10^{-3}$ & $5.97 \times 10^{-2}$ & 0.98 \\
\hline & & & & & elevation & $2.29 \times 10^{-6}$ & $4.41 \times 10^{-5}$ & 0.96 \\
\hline
\end{tabular}


566 Table 4 Models used to test the effects of body size on reproductive traits

\begin{tabular}{|c|c|c|c|c|c|c|c|c|c|c|c|}
\hline & & Initial model & Model & Response variable & $F$ & D.f. & $R^{2}$ & $p$ & Explanatory variables & $F$ & $p$ \\
\hline \multirow[t]{3}{*}{$\begin{array}{l}\text { Effect of body size on } \\
\text { clutch size }\end{array}$} & for all species & clutch size $\sim$ species*body size & ANCOVA & clutch size & 691.6 & 744 & 0.87 & $<0.0001$ & species & 24.89 & $<0.0001$ \\
\hline & & & & & & & & & body size & 98.37 & $<0.0001$ \\
\hline & & & & & & & & & species : body size & 27.81 & $<0.0001$ \\
\hline \multirow[t]{3}{*}{$\begin{array}{l}\text { Effect of body size on } \\
\text { mean egg volume }\end{array}$} & for all species & $\begin{array}{l}\text { mean egg volume } \sim \text { species*body } \\
\text { size }\end{array}$ & ANCOVA & mean egg volume & 75.73 & 447 & 0.54 & $<0.0001$ & species & 1.16 & 0.33 \\
\hline & & & & & & & & & body size & 2.09 & 0.15 \\
\hline & & & & & & & & & species : body size & 0.91 & 0.44 \\
\hline
\end{tabular}




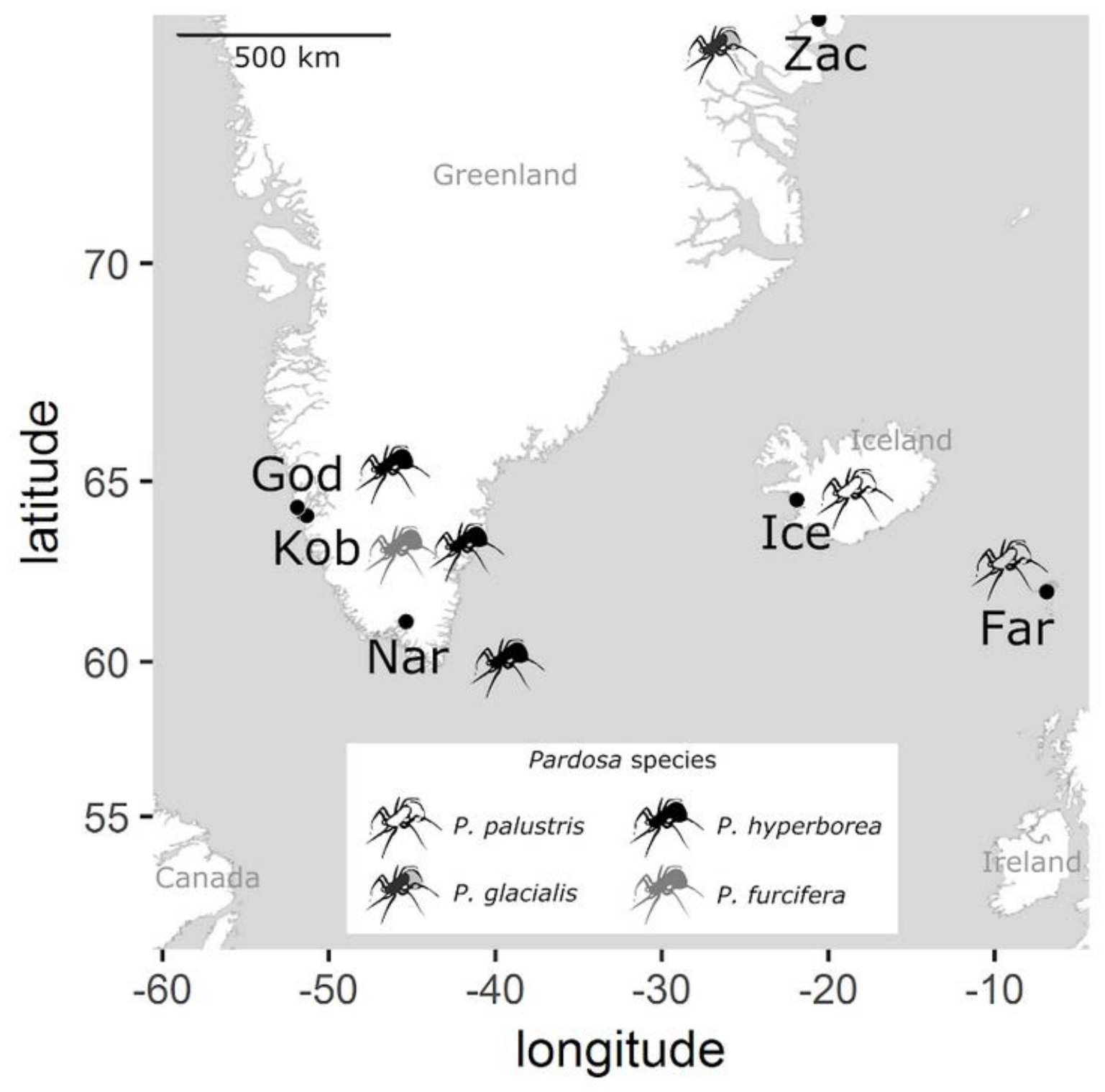

570 Fig.1 Map of the collecting sites of Pardosa species. From North to South: Zac: Zackenberg (74.467N,

$57120.566 \mathrm{~W})$, Ice: Iceland (64.700N, 21.500W), God: Godthaabsfjord (64.144N, 51.474W), Kob:

572 Kobbefjord (64.117N, 51.350W), Far: Faroe Islands (62.041N, 6.877W), Nar: Narsarsuaq (61.183N,

573 45.371W). Latitude and longitude in Decimal Degrees WGS84. 


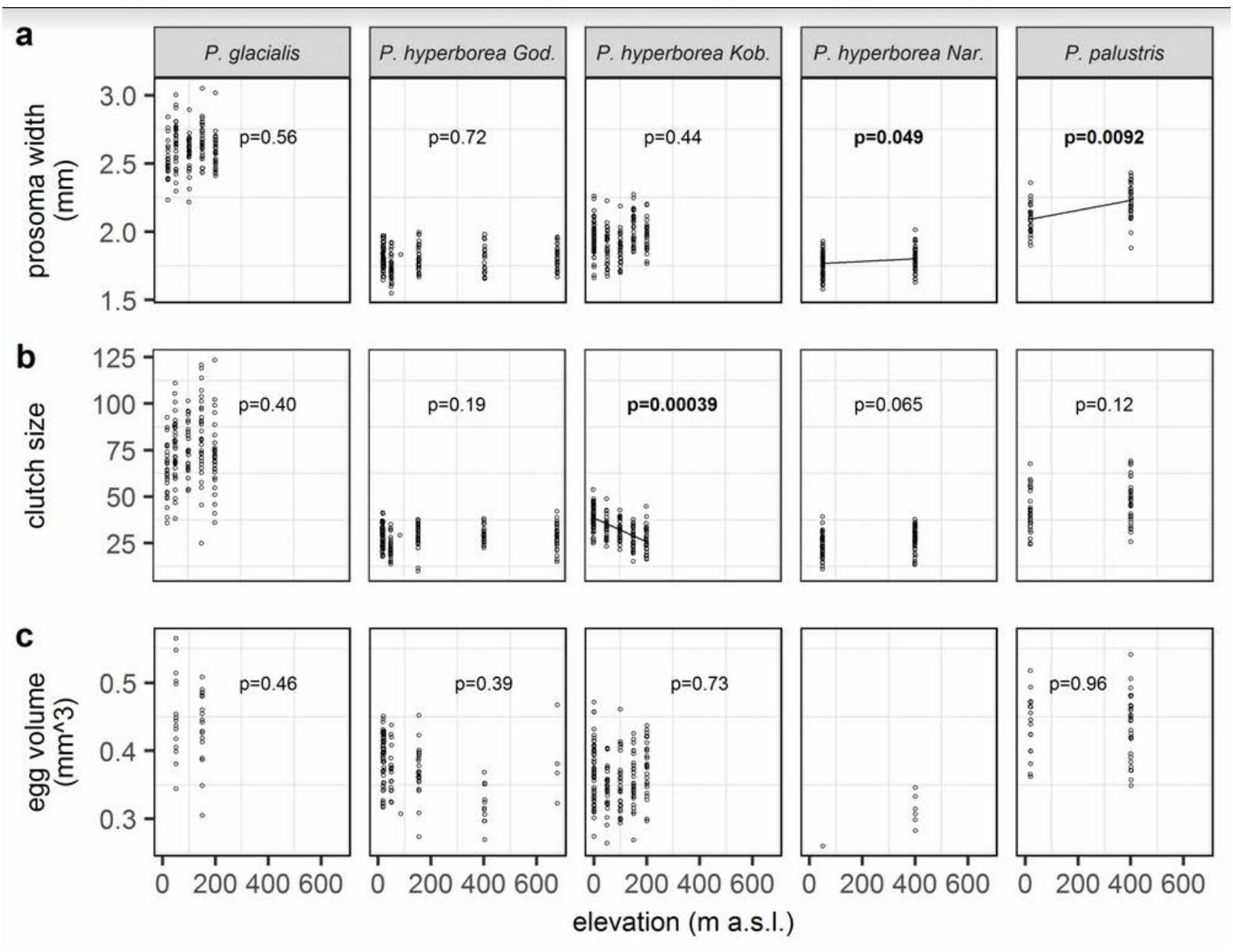

Fig.2 Effect of elevation on body size, clutch size and mean egg volume. a. body size, $\mathbf{b}$. clutch size,

576 c. mean egg volume. Sample size was too low for $P$. hyperborea in Narsarsuaq to apply a statistical

577 test $(n=5)$. Significant values are written in bold. Applied models are detailed in Table 3 

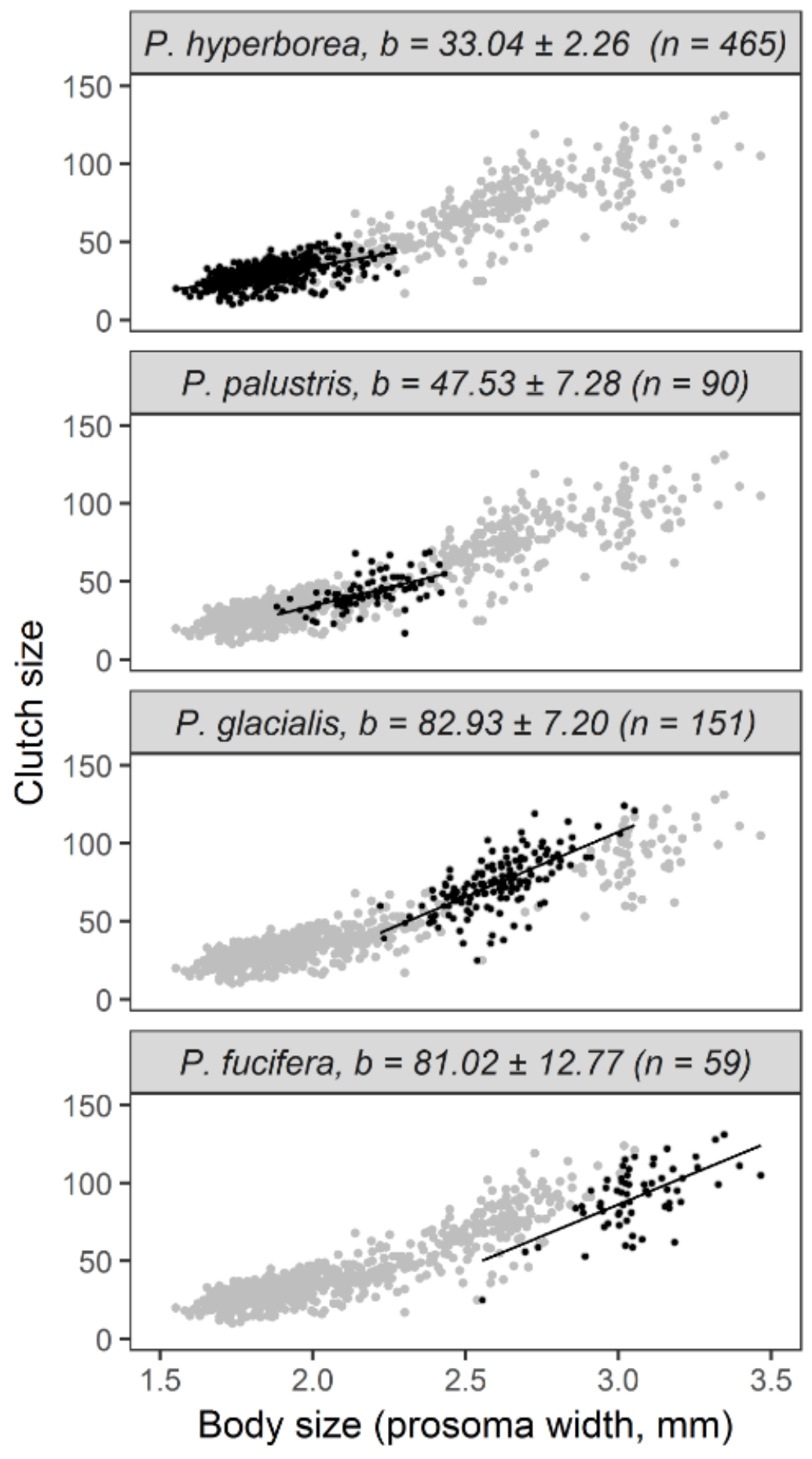

579 Fig.3 Linear regression results of clutch size on female size. Formulas are written as follows: $y=a+$ $580 b * x$. Pardosa hyperborea: $L L S R$, clutch $=-31.68+33.04^{*}$ size $, F_{445}=212.7, R^{2}=0.32, p<0.0001, P$. 581 palustris: $L S S R$, clutch $=-60.52+47.53^{\star}$ size, $F_{88}=42.67, R^{2}=0.32, p<0.0001, P$. glacialis: $L L S R$, 582 clutch $=-141.42+82.93^{\star}$ size, $F_{149}=132.7, R^{2}=0.47, p<0.0001, P$. furcifera: $L L S R$, Clutch $=-159.28$ $583+81.02 *$ prosoma width, $F_{57}=30.49, R^{2}=0.34, p<0.0001$ 
Elevational variation of body size and reproductive traits in high latitude wolf spiders (Araneae: Lycosidae)

Polar Biology

Camille Ameline (corresponding author), Toke Thomas Høye, Joseph James Bowden, Rikke Reisner Hansen, Oskar Liset Pryds Hansen, Charlène Puzin, Philippe Vernon, Julien Pétillon

Corresponding author: cameline8@gmail.com

Online Resource 1 Description of the four species collected on the field. References: 1: Vlijm 1971, 2: Bengtson et al. 1976, 3: Ashmole and Planterose 1979, 4: Bengtson and Hauge 1979, 5: Koponen 1987, 6: Dondale and Redner 1990, 7: Buchar 1993 , 8: Koponen 2002, 9: Cameron et al. 2004, 10: Marusik et al. 2006, 11: Fet and Popov 2007, 12: Hammel and Nickel 2008, 13: Høye and Hammel 2010, 14: Bowden and Buddle 2010, 15: Koponen 2011, 16: Růžička et al. 2012, 17: Hein et al. 2015 , 18: Hein et al. 2014, 19: Nentwig et al. 2015, 20: Natural History Museum Bern 2015, 21: Marusik 2015, 22: Hansen et al. 2016

\begin{tabular}{|c|c|c|c|c|}
\hline Species & Description & Distribution & Habitat specialisation & Elevation (m a.s.I.) \\
\hline P. glacialis & Thorell 1872 & $\begin{array}{l}\text { Holarctic }{ }^{[20]} \text {, Nearctic, } \\
\text { Arctic, Greenland (G) }\end{array}$ & not specified & $0-860^{[13,14,15]}$ \\
\hline P. hyperborea & Thorell 1872 & $\begin{array}{l}\text { Holarctic }{ }^{[20]} \text {, low Arctic- } \\
\text { boreal }{ }^{[21]} \text {, Greenland (S, } \\
\text { SW north to Disko, SE north } \\
\text { to } 70^{\circ} 50^{\prime} \mathrm{N} \text { ) }\end{array}$ & rare psychrophilous ${ }^{[7]}$ & $100-1360^{[3,5,12,13,14,15,18]}$ \\
\hline$P$. furcifera & Thorell 1875 & $\begin{array}{l}\text { Canada, Alaska, Greenland } \\
\left(\mathrm{S}, \mathrm{SW}^{[21]}\right) \text {, Iceland }{ }^{[20]} \text { : } \\
\text { trans-Nearctic arcto-alpine } \\
\text { range }^{[10,21]}\end{array}$ & not specified & $0-1360^{[13,14,15]}$ \\
\hline P. palustris & $\begin{array}{l}\text { Linnaeus } \\
1758\end{array}$ & Holarctic ${ }^{[20]}$ & $\begin{array}{l}\text { generalist }^{[7]} \text { (widespread, }^{[1]} \\
\text { especially in cold climates) }\end{array}$ & up to $2500^{[2,7,9,11]}$ \\
\hline Species & \multicolumn{4}{|c|}{ Found habitats } \\
\hline P. glacialis & \multicolumn{4}{|c|}{$\begin{array}{l}\text { in heaths }{ }^{[21]} \text { and sedge meadows, among lichens and low shrubs, and on beaches or bare soil on Arctic tundra }{ }^{[6]} \text {, transition } \\
\text { boreal forest to Arctic tundra }{ }^{[14]} \text {, sub-Arctic pine forest area, birch woods, bogs }{ }^{[21]} \text { and treeless fells }{ }^{[15]}\end{array}$} \\
\hline P. hyperborea & \multicolumn{4}{|c|}{$\begin{array}{l}\text { open forests and moors }{ }^{[19]} \text {, birch wood }{ }^{[2,15]} \text {, sphagnum bogs (in boreal zones }{ }^{[8]} \text { ), low-lying spruce forests, rocky hillsides, } \\
\text { among lichens in Arctic and alpine tundra and on needle mats in forests ofjack pine, black spruce, and balsam fir }{ }^{[6]} \text {, } \\
\text { transition boreal forest to Arctic tundra }{ }^{[14]} \text {, sub-Arctic pine forest area, birch woods, bogs and treeless fells }{ }^{[15]} \text {, south-facing } \\
\text { dry slopes }{ }^{[21]} \text {, heath habitats }{ }^{[22]}\end{array}$} \\
\hline$P$. furcifera & \multirow{2}{*}{\multicolumn{4}{|c|}{$\begin{array}{l}\text { spruce-pine forests, in willow clumps near the timberline, and on moss and stones in alpine tundra }{ }^{[6]} \text {, sub-Arctic pine forest } \\
\text { area, birch woods, bogs and treeless fells }{ }^{[15]} \text {, transition boreal forest to Arctic tundra }{ }^{[14]} \text {, on rather moist ground and in Salix } \\
\text { herbacea snow beds as well as in the moss layer of heaths adjoining brooks. Also in herb fields on slopes and in Salix } \\
\text { glauca thickets }{ }^{[21]} \\
\text { open, dry areas }{ }^{[19,17,1]} \text {, tidal drifts on a saltwater beach, along grassy margins of streams, above timberline in mountain } \\
\text { passes }{ }^{[6]} \text {, rich grassland, poor grassland, ash woodland }{ }^{[9]}, \text { tundra, mire }{ }^{[16,18]} \text {, tall herb meadow, grass meadow, birch wood } \\
\text { (open ground and sparse woods) }{ }^{[1,2,3]} \text {, pastures, heaths }{ }^{[1]} \text {, bogs }{ }^{\left[{ }^{[0]},\right.} \text {, braided rivers }{ }^{[3]} \text {, grass and dwarf shrub heaths and } \\
\text { open infield meadows }{ }^{[4]}\end{array}$}} \\
\hline P. palustris & & & & \\
\hline
\end{tabular}

G: global, S: south, W: west, N: north, E: east 


\section{References}

Ashmole NP, Planterose BR (1979) Spiders from arctic Fennoscandia. Norw J Entomol 26:26-30

Bengtson S-A, Hauge E (1979) Terrestrial invertebrates of the Faroe Islands: I. Spiders (Araneae): Check-list, distribution, and habitat. Norw J Entomol 26:59-83

Bengtson S-A, Nilsson A, Nordstrom S, Rundgren S, Hauge E (1976) Species composition and distribution of spiders (Aranea) in Iceland. Norw J Entomol 23:35-39

Marusik, YM (2015) Araneae (Spiders). In: Bøcher J, Kristensen NP, Wilhelmsen L (2015) The Greenland entomofauna. An identification manual of insects, spiders and their allies, vol 44. Fauna Entomologica Scandinavica, Brill, Leiden

Bowden J, Buddle C (2010) Determinants of ground-dwelling spider assemblages at a regional scale in the Yukon Territory, Canada. Ecoscience 17:287-297

Buchar J (1993) Biogeographical and ecological relations of wolf spiders in Czechoslovakia and in Central Europe. Boll Acc Gioenia Sci Nat 26:27-34

Cameron A, Johnston RJ, McAdam J (2004) Classification and evaluation of spider (Araneae) assemblages on environmentally sensitive areas in Northern Ireland. Agr Ecosyst Environ 102:29-40

Dondale CD, Redner JH (1990) The wolf spiders, nurseryweb spiders, and lynx spiders of Canada and Alaska: Araneae:Lycosidae, Pisauridae, and Oxyopidae. Research Branch, Agriculture Canada, Ottawa

Fet V, Popov A (2007) Biogeography and ecology of Bulgaria. Springer, Dordrecht

Hammel JU, Nickel M (2008) Pardosa hyperborea (Araneae: Lycosidae): A first report from Disko Island (West Greenland), with remarks on the biogeography of the species. Ent Meddr 76:41-47

Hansen RR, Hansen OLP, Bowden JJ, Treier UA, Normand S, Høye TT (2016) Meter scale variation in shrub dominance and soil moisture structure Arctic arthropod communities. PeerJ 4: e2224

Hein N, Feilhauer H, Löffler J, Finch O-D (2015) Elevational variation of reproductive traits in five Pardosa (Lycosidae) species. Arct Antarct Alp Res 47:473-479

Hein N, Feilhauer H, Finch O-D, Schmidtlein S, Löffler J (2014) Snow cover determines the ecology and biogeography of spiders (Araneae) in alpine tundra ecosystems. Erdkunde 68:157-172

Høye T, Hammel J (2010) Climate change and altitudinal variation in sexual size dimorphism of arctic wolf spiders. Climate Res 41:259-265

Koponen S (1987) Communities of ground-living spiders in six habitats on a mountain in Quebec, Canada. Ecography 10:278-285

Koponen S (2002) Ground-living spiders in bogs in Northern Europe. J Arachnol 30:262-267

Koponen S (2011) Ground-living spiders (Araneae) at polluted sites in the Subarctic. Arachnol Mitt 40:80-84

Marusik YM, Böcher J, Koponen S (2006) The collection of Greenland spiders (Aranei) kept in the Zoological Museum, University of Copenhagen. Arthropoda Sel 15:59-80

Natural History Museum Bern (2015) World Spider Catalog. In: World Spider Catalog. http://wsc.nmbe.ch. Accessed 3 May 2015

Nentwig W, Blick T, Gloor D, Hänggi A, Kropf C (2015) Spiders of Europe. In: Spiders of Europe. www.araneae.unibe.ch. Accessed 3 Jun 2015

Růžička V, Vaněk J, Šmilauer P (2012) Spiders in mountain habitats of the Giant Mountains. Russ J Ecol+ 43:341-347

Vlijm (1971) Some notes on the occurence of the genus Pardosa (Lycosidae, Araneae) in Southern France, Spain and Corsica. Zool Meded 45:281-288 
Elevational variation of body size and reproductive traits in high latitude wolf spiders (Araneae: Lycosidae)

Polar Biology

Camille Ameline (corresponding author), Toke Thomas Høye, Joseph James Bowden, Rikke Reisner Hansen, Oskar Liset Pryds Hansen, Charlène Puzin, Philippe Vernon, Julien Pétillon

Corresponding author: cameline8@gmail.com

Online Resouce 2 Detailed maps of sampling sites. Dots represent collection sites. In Zackenberg and Kobbefjord, $2 \mathrm{~km}$ elevation gradients are represented with a segment. Zackenberg: A-B: 20-200 m a.s.I.; Kobbefjord: 0-200 m a.s.l; Godthaabsfjord: A: $18 \mathrm{~m}$ a.s.I., B: $20 \mathrm{~m}$ a.s.I., C: 50,150 and $400 \mathrm{~m}$ a.s.I., D: $678 \mathrm{~m}$. a.s.I.; Narsarsuaq: A: 40-50 m a.s.I., B: 400-430 m a.s.l.; Iceland: A: $20 \mathrm{~m}$ a.s.I., B: $400 \mathrm{~m}$ a.s.I.; Faroe Islands: $350 \mathrm{~m}$ a.s.I. 


\section{Zackenberg}
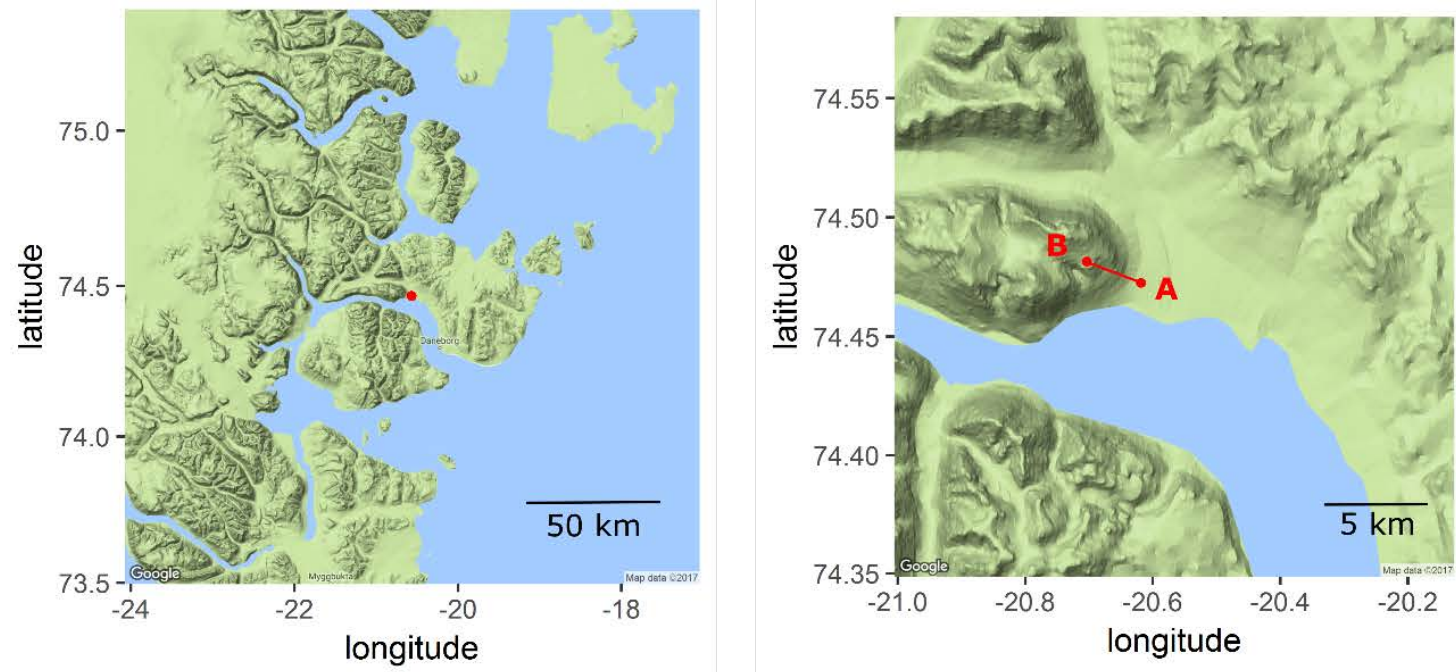

Kobbefjord
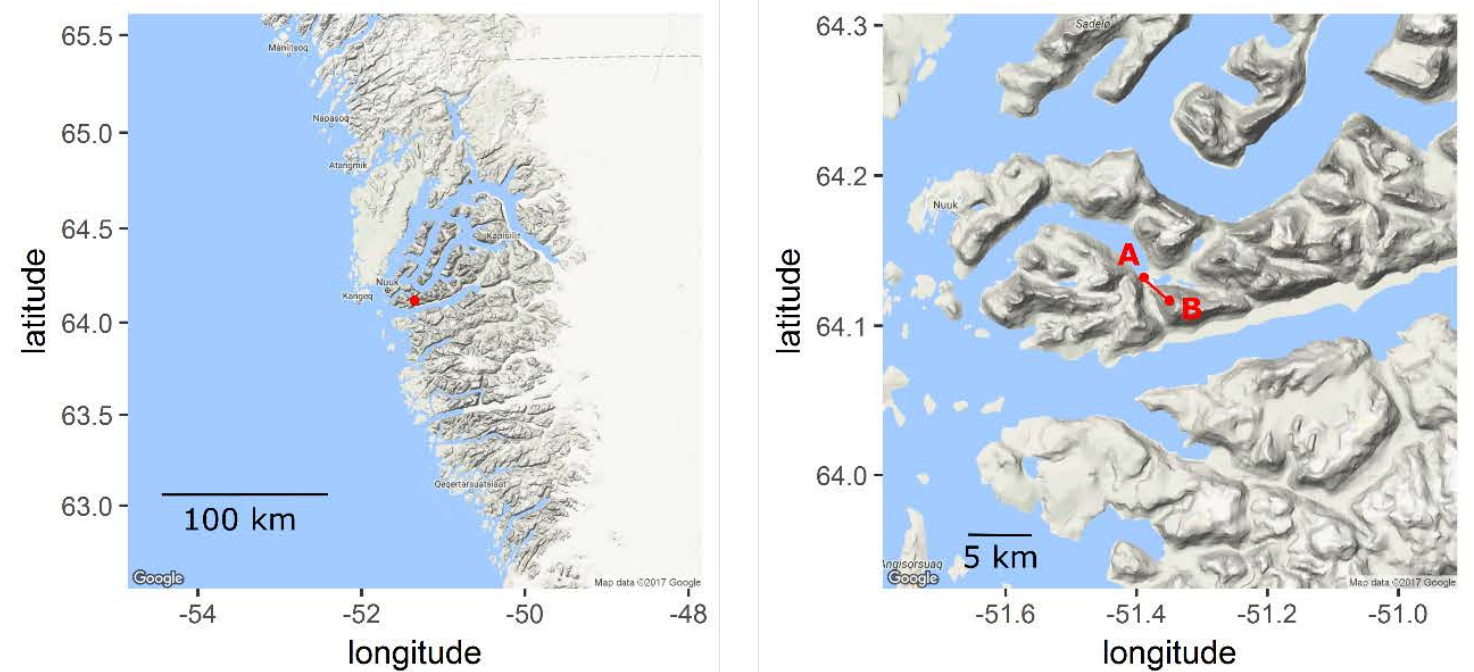

Godthaabsfjord
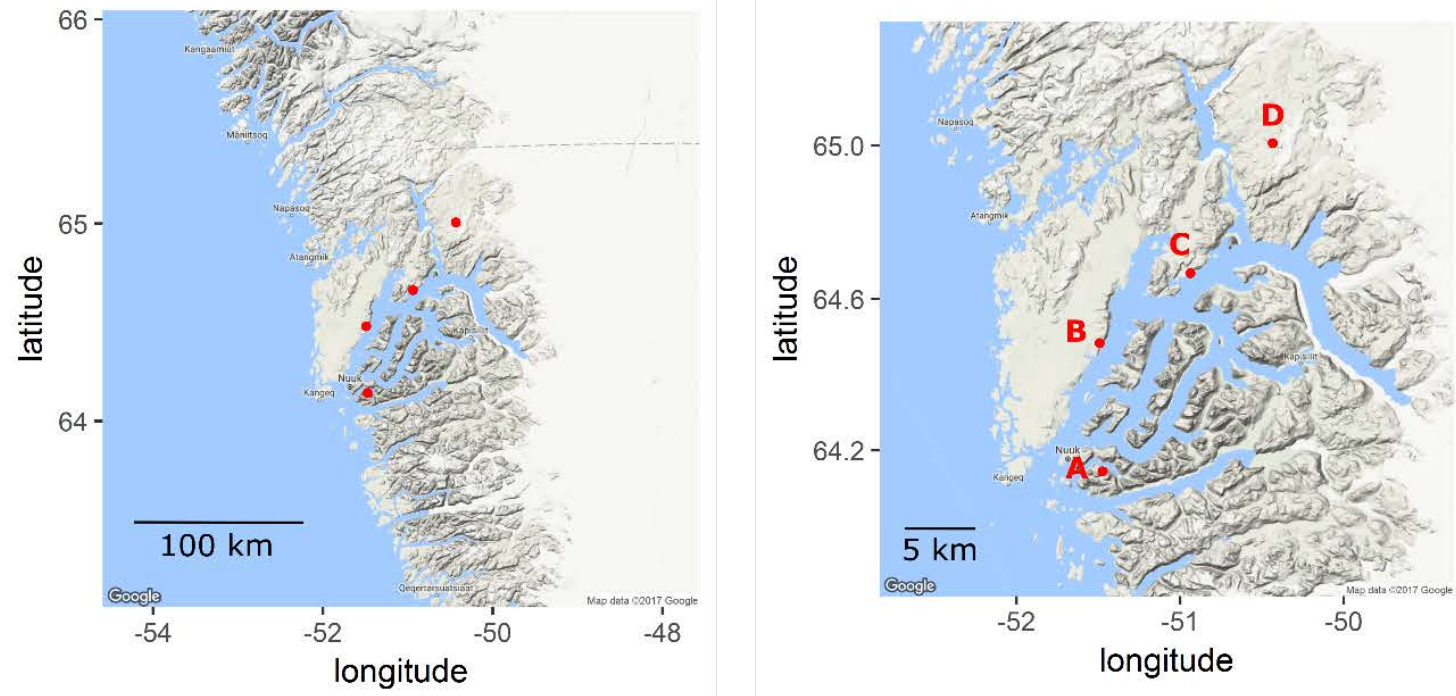
Narsarsuaq
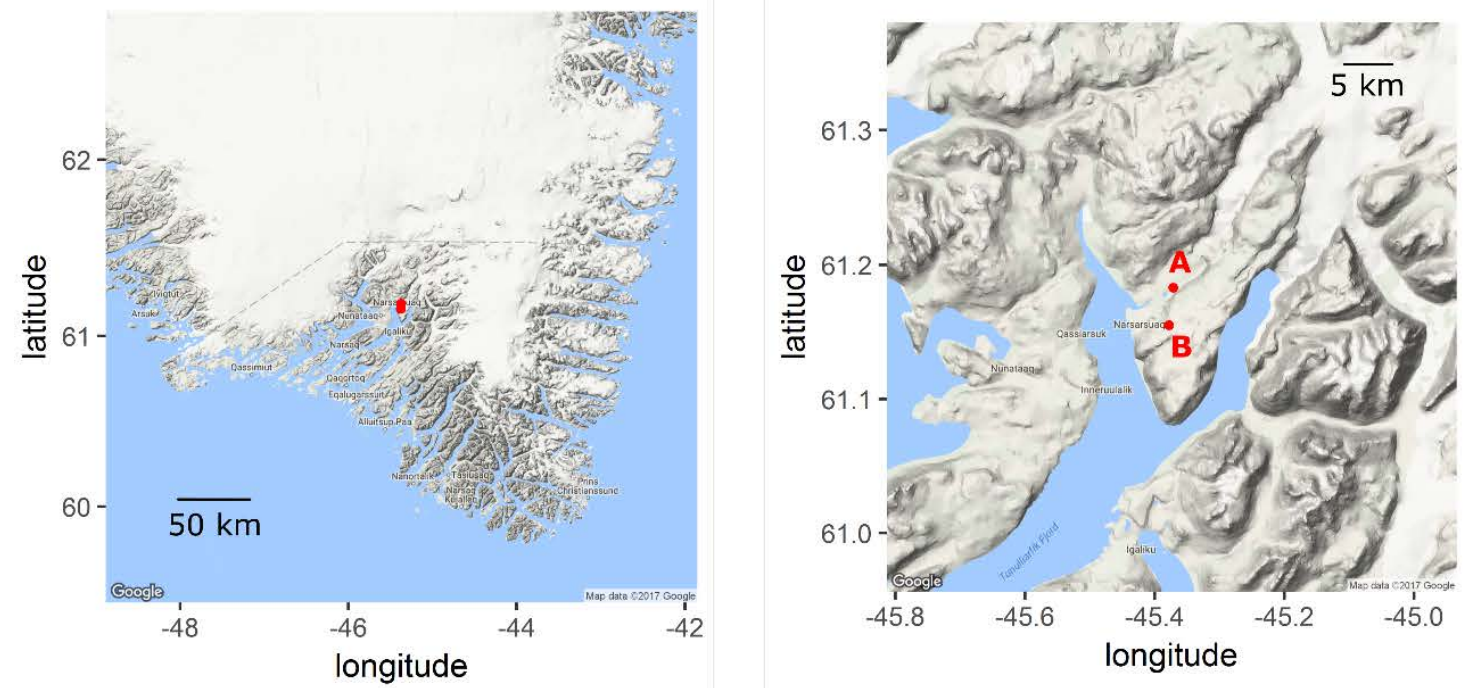

Iceland
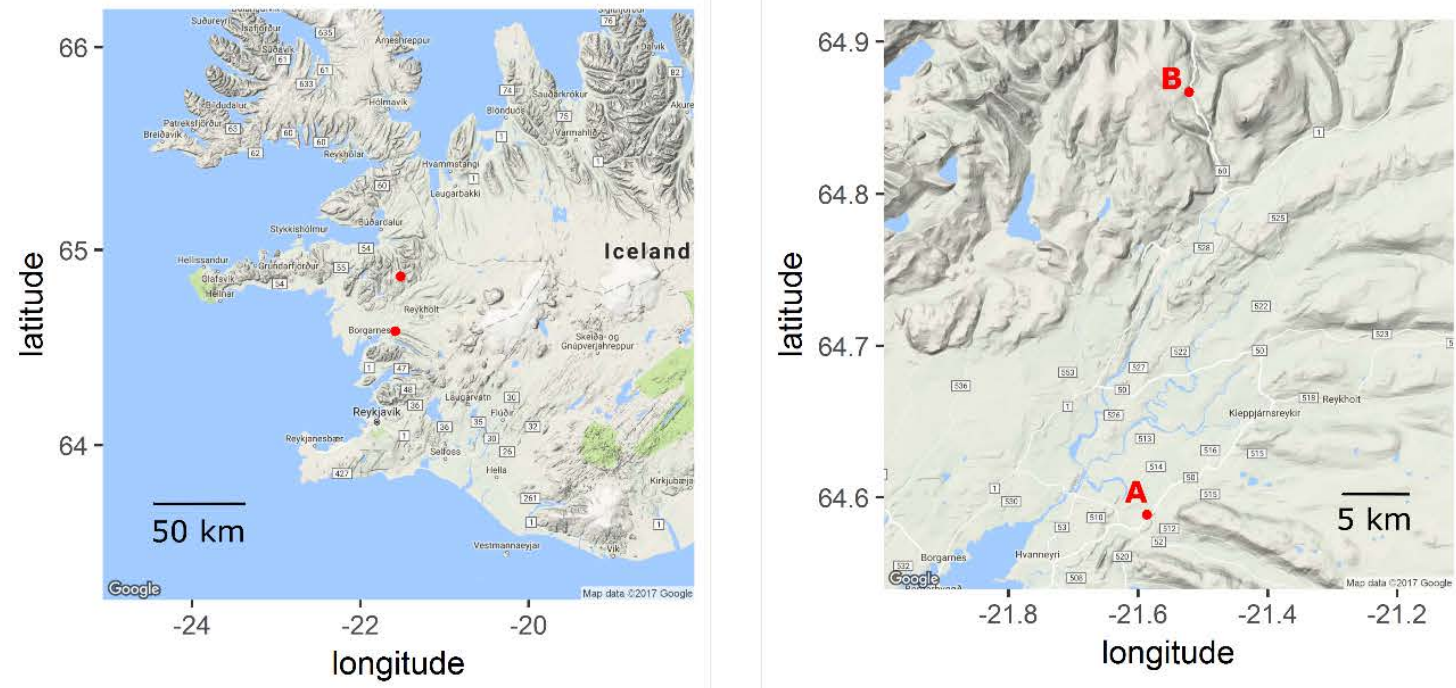

Faroe Islands
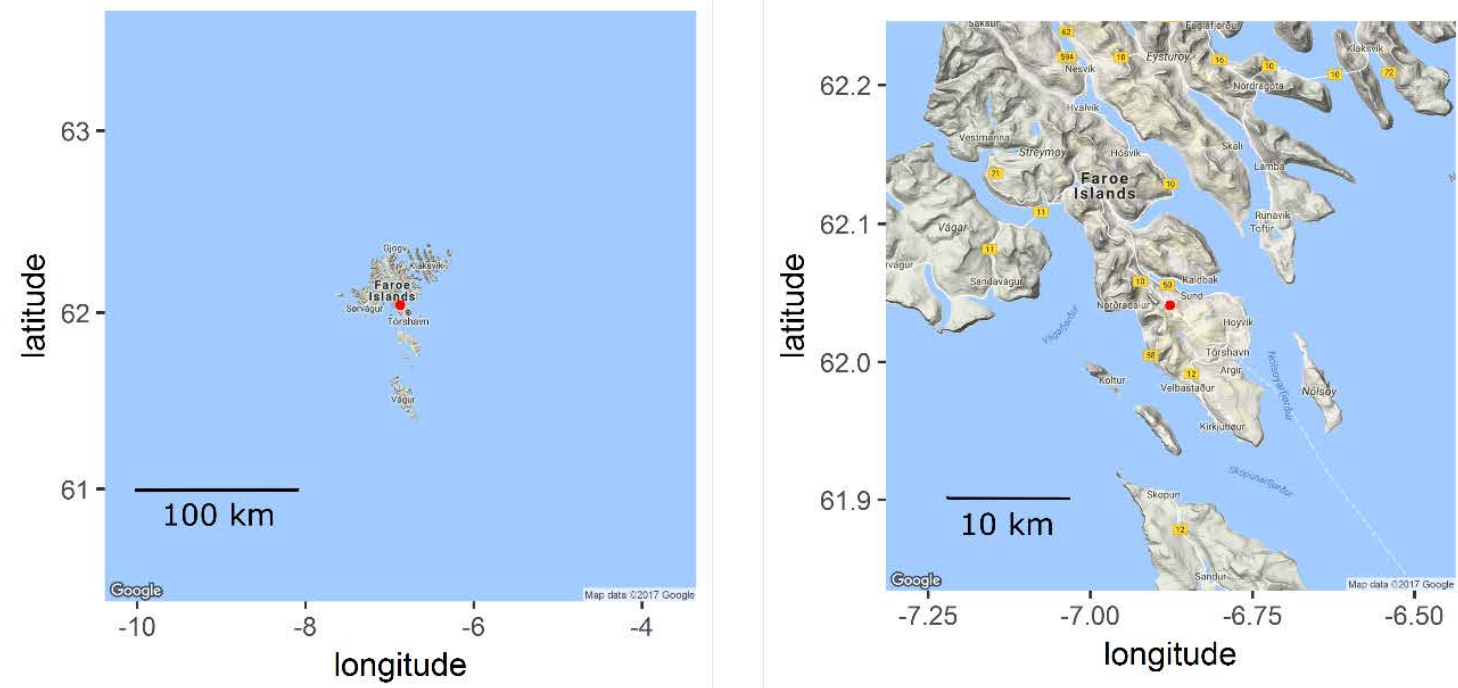
Elevational variation of body size and reproductive traits in high latitude wolf spiders (Araneae: Lycosidae)

Polar Biology

Camille Ameline (corresponding author), Toke Thomas Høye, Joseph James Bowden, Rikke Reisner Hansen, Oskar Liset Pryds Hansen, Charlène Puzin, Philippe Vernon, Julien Pétillon

Corresponding author: cameline8@gmail.com

Online Resource 3 Fig.1.1 to 1.6: body measurements and species' prosomas. Fig.2.1 to 2.3: parasitoid developmental stages. Fig.3.1 to 3.12: eggs developmental stages. Arrows represent the measurements. We used a EUROMEX trinocular stereomicroscope 45X connected with a CMEX5000 camera. Pictures and measurements were taken with the software Euromex ImageFocus v3.0. 


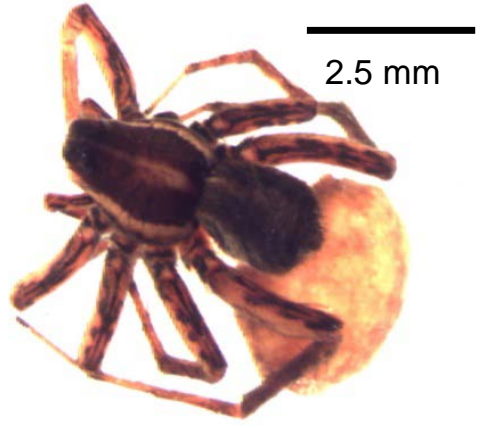

Fig.1.1 Pardosa palustris carrying egg sac

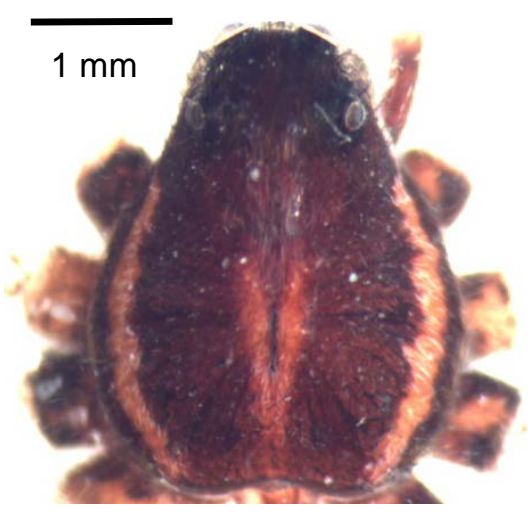

Fig.1.4 P. glacialis' prosoma

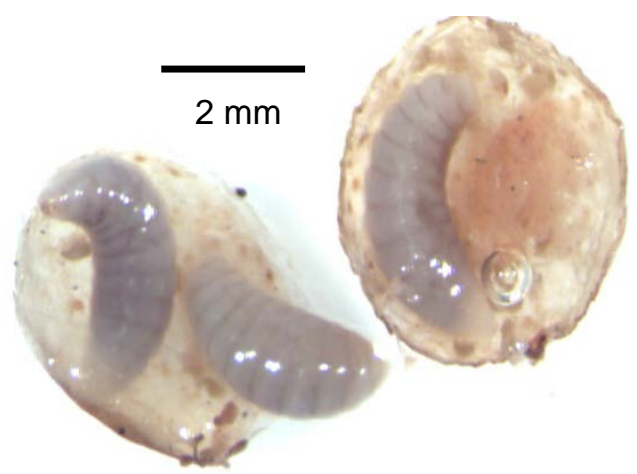

Fig.2.1 Parasitoid larvae in egg sac

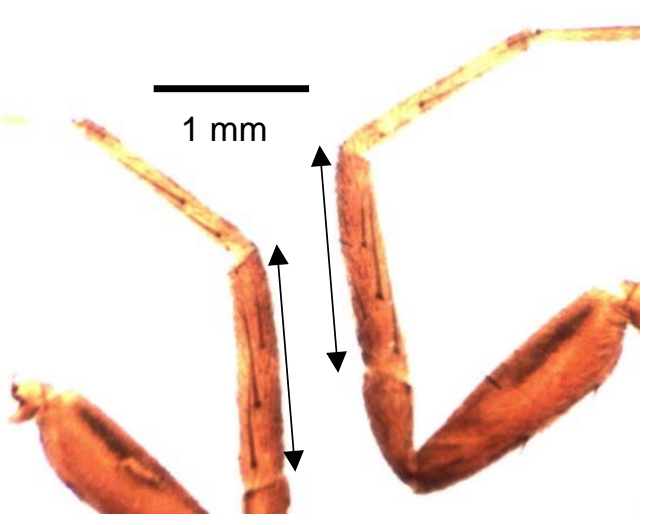

Fig.1.2 Leg 1's tibias measurement

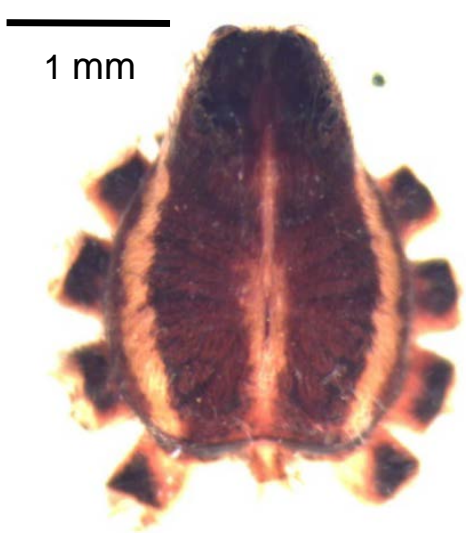

Fig.1.5 P. palustris' prosoma

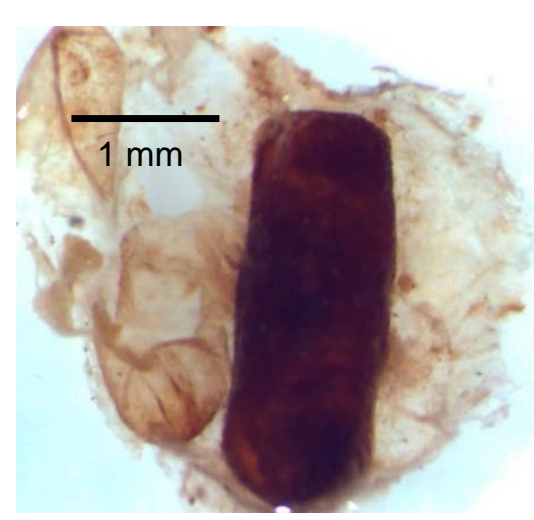

Fig.2.2 Parasitoid pupae in egg sac

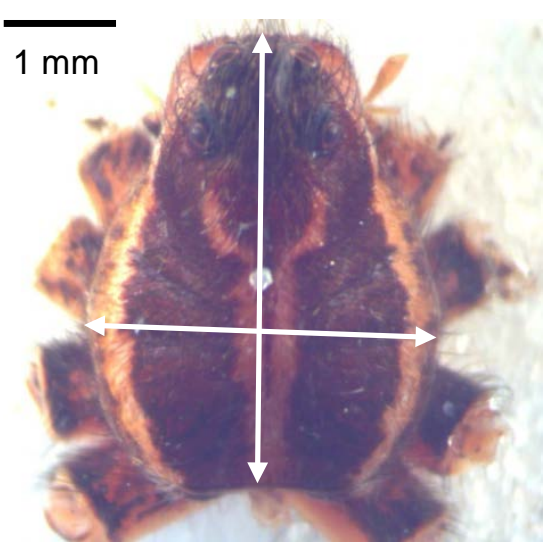

Fig.1.3 P. furcifera's prosoma

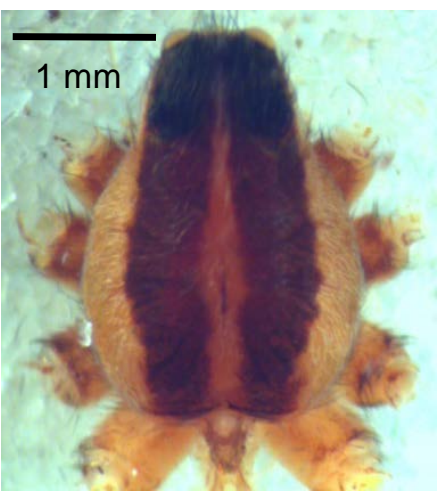

Fig.1.6 P. hyperborea's prosoma

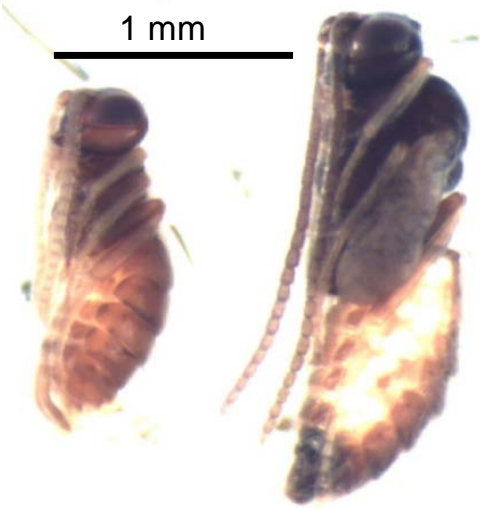

Fig.2.3 Parasitoid teneral adults of Gelis sp.. Left: wingless +, right: $\delta$ with wings not entirely developed 


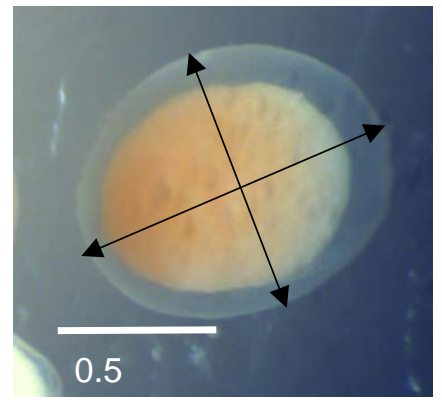

Fig.3.1 Egg development stage I

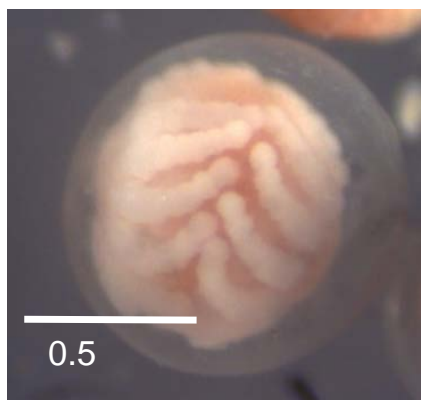

Fig.3.4 Stage II

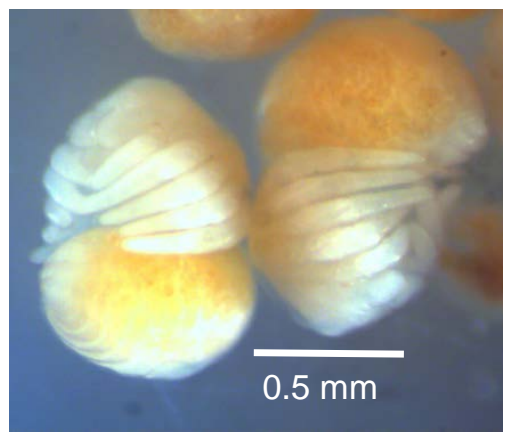

Fig.3.7 Stage IV

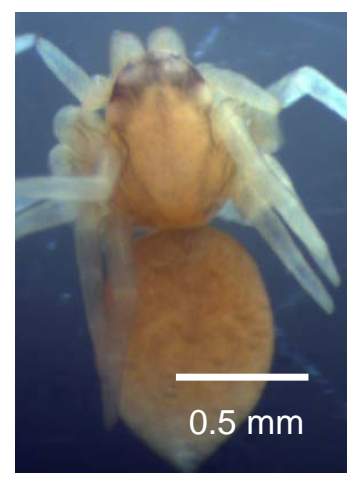

Fig.3.10 Stage $V$

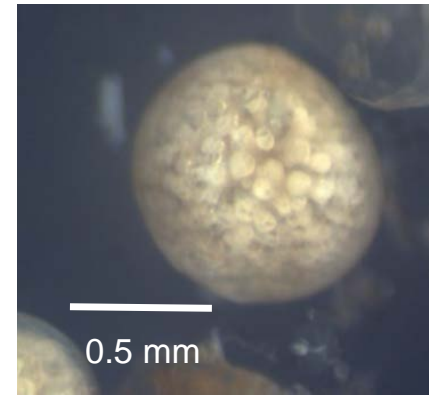

Fig.3.2 Stage I

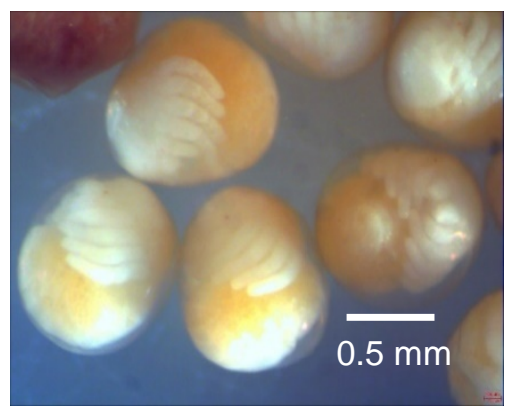

Fig.3.5 Stage III

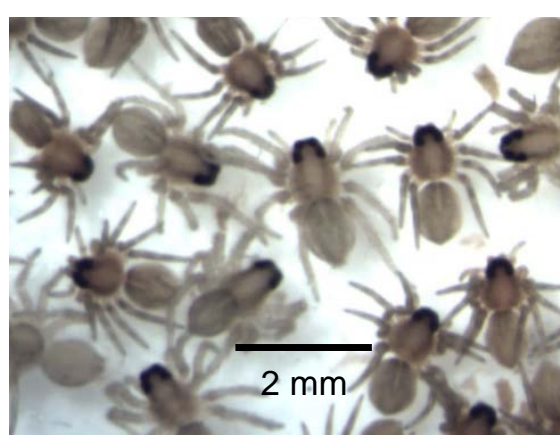

Fig.3.8 Stage V

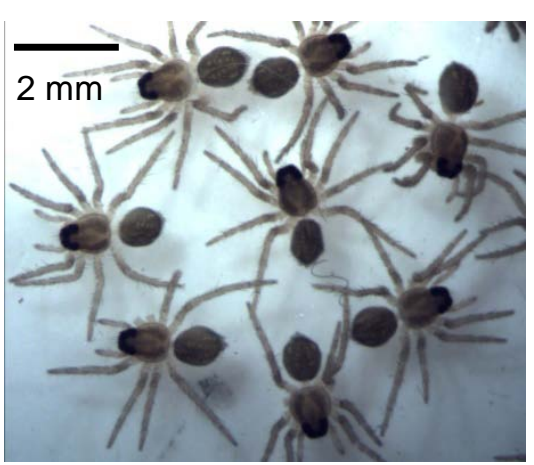

Fig.3.11 Stage VI

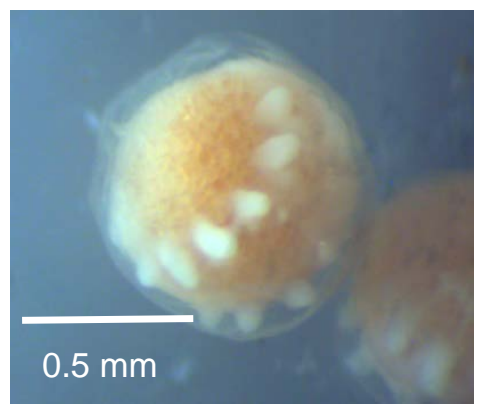

Fig.3.3 Stage II

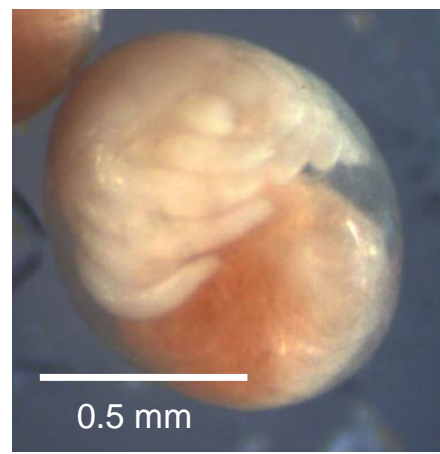

Fig.3.6 Stage III

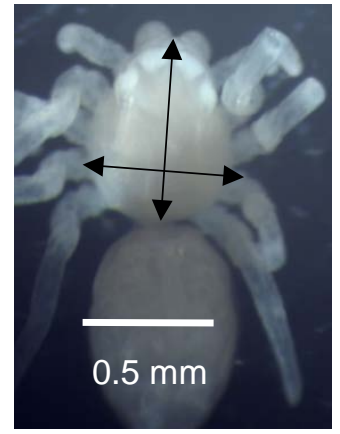

Fig.3.9 Stage $V$

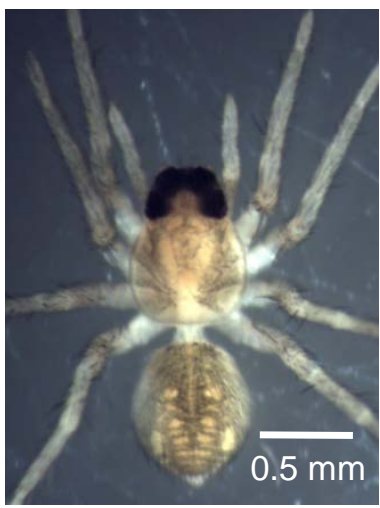

Fig.3.12 Stage VI 
Elevational variation of body size and reproductive traits in high latitude wolf spiders (Araneae: Lycosidae)

Polar Biology

Camille Ameline (corresponding author), Toke Thomas Høye, Joseph James Bowden, Rikke Reisner Hansen, Oskar Liset Pryds Hansen, Charlène Puzin, Philippe Vernon, Julien Pétillon

Corresponding author: cameline8@gmail.com

Online Resource 4 Fig. 1: Development stages of eggs in egg sac along elevational gradient per species and site. Development stages: I - VI (see methods). Mean egg volume could only be measured for stages I to III.

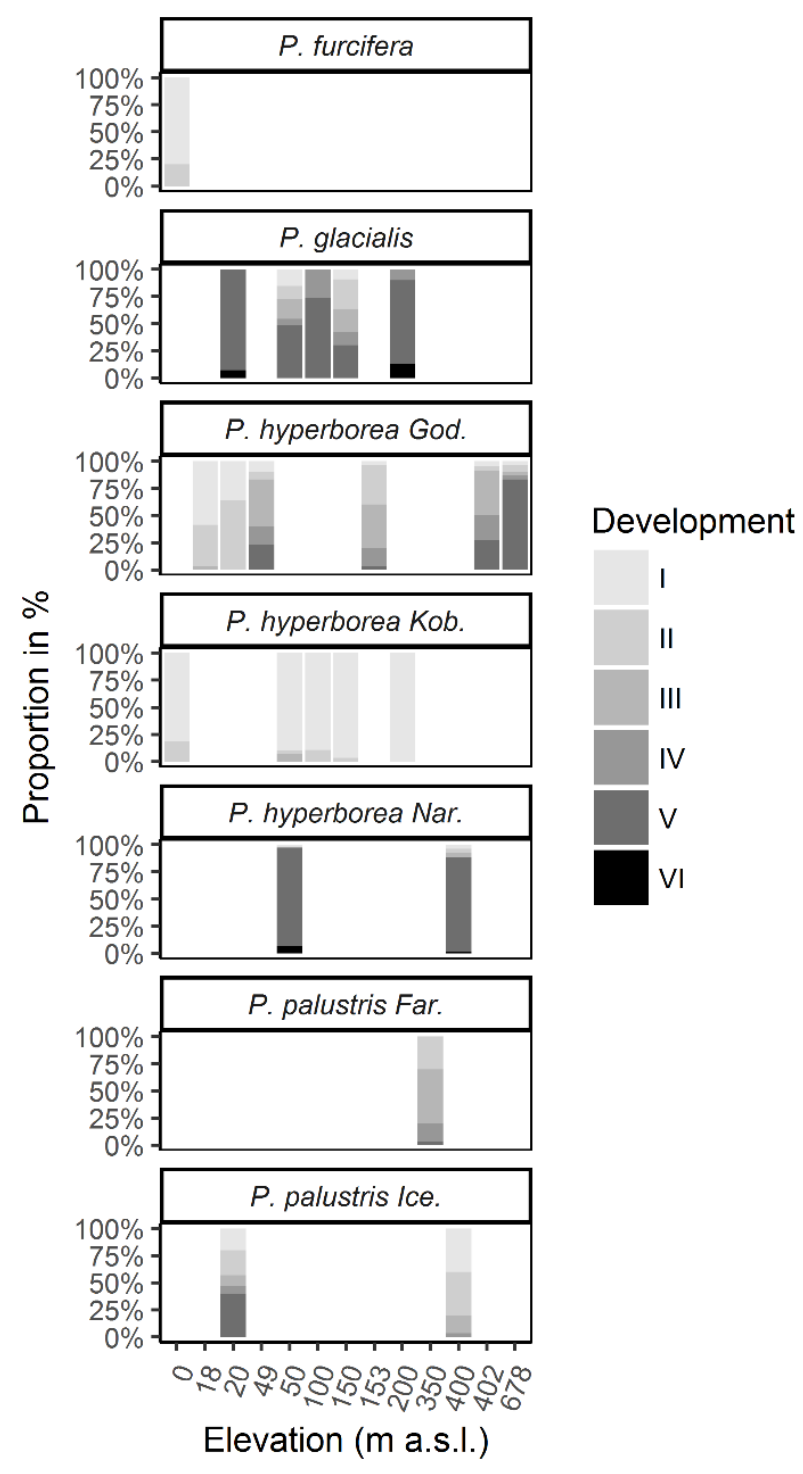


Elevational variation of body size and reproductive traits in high latitude wolf spiders (Araneae: Lycosidae)

Polar Biology

Camille Ameline (corresponding author), Toke Thomas Høye, Joseph James Bowden, Rikke Reisner Hansen, Oskar Liset Pryds Hansen, Charlène Puzin, Philippe Vernon, Julien Pétillon

Corresponding author: cameline8@gmail.com

Online Resource 5 Fig. 1: Normal distribution of the measured variables. Histograms show the distribution of the measured variable. Corresponding panels on the right show Quantile-Quantile plots (x-axis: Theoretical quantiles, y-axis: Sample quantiles). They were no hatched eggs in female $P$. glacialis and $P$. hyperborea in Kobbefjord. Two distinct distributions in the postembryonic measurements correspond to development stages V and VI. God: Godthaabsfjord, Kob: Kobbefjord, Nar: Narsarsuaq, Far: Faroe Islands, Ice: Iceland. PE: postembryonic. 


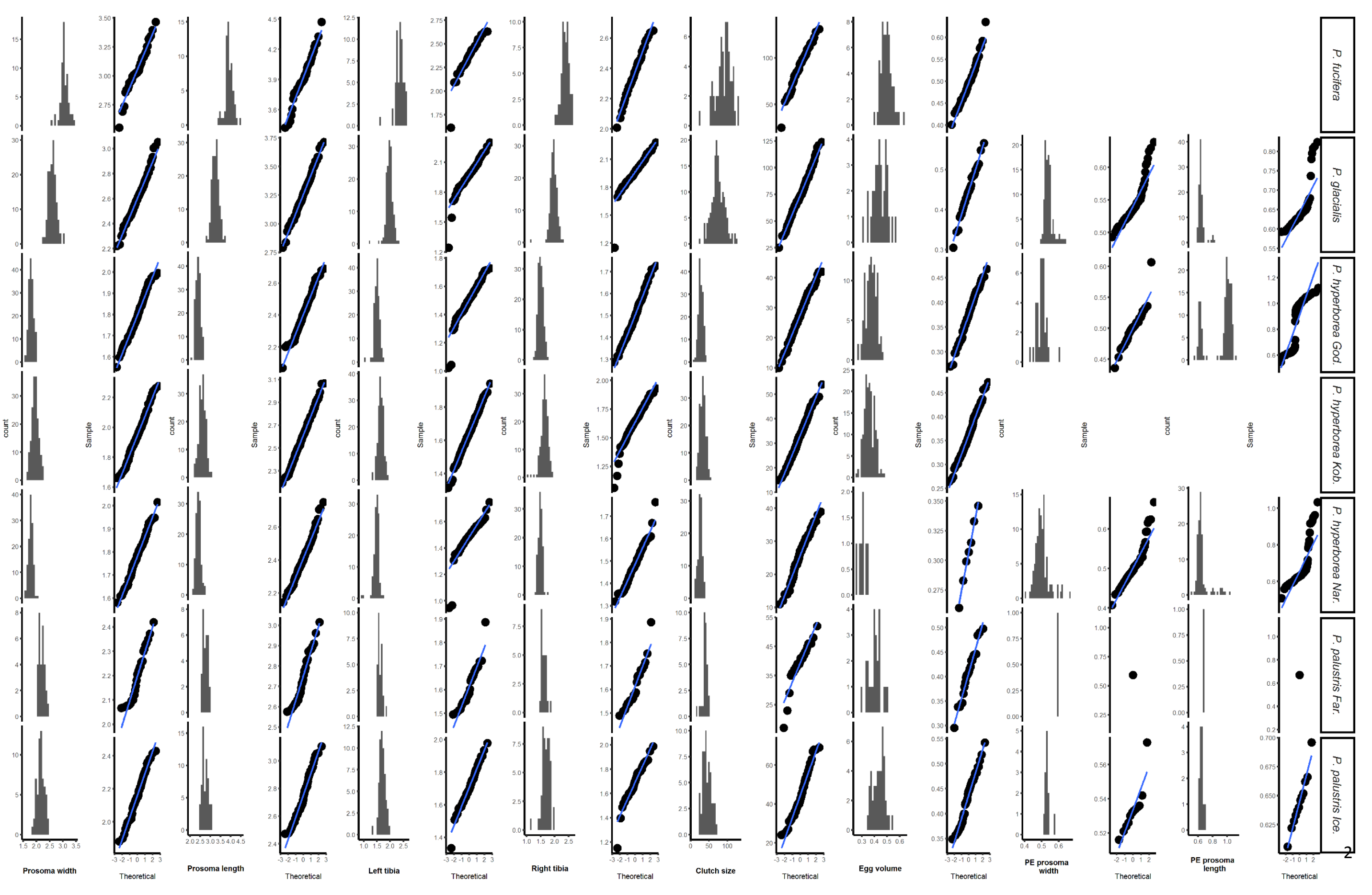

